I NTERNATIONAL MONETARY FUND

European Department

Macroprudential Policies and House Prices in Europe

Marco Arena, Tingyun Chen, Seung Mo Choi, Nan Geng, Cheikh Anta Gueye, Tonny Lybek, Evan Papageorgiou, and Yuanyan Sophia Zhang

No. $20 / 03$ 
European Department

\section{Macroprudential Policies and House Prices in Europe}

Marco Arena, Tingyun Chen, Seung Mo Choi, Nan Geng, Cheikh Anta Gueye, Tonny Lybek, Evan Papageorgiou, and Yuanyan Sophia Zhang

I N TER N A T I O N A L M O NETAR Y F U N D CInternational Monetary Fund. Not for Redistribution 
Copyright @2020 International Monetary Fund

\section{Cataloging-in-Publication Data IMF Library}

Names: Arena, Marco, author. | Chen, Tingyun, author. | Choi, Seung Mo, author. | Geng, Nan, author. Gueye, Cheikh A. (Cheikh Anta), author. | Lybek, Tonny, author. | Papageorgiou, Evangelos, 1980-, author. | Zhang, Yuanyan Sophia, author. | International Monetary Fund. European Department, issuing body. | International Monetary Fund, publisher.

Title: Macroprudential policies and house prices in Europe / Marco Arena, Tingyun Chen, Seung Mo Choi, Nan Geng, Cheikh Anta Gueye, Tonny Lybek, Evan Papageorgiou, and Yuanyan Sophia Zhang. Other titles: International Monetary Fund. European Department (Series).

Description: Washington, DC : International Monetary Fund, 2019. | At head of title: European Department. | Departmental paper series. | Includes bibliographical references.

Identifiers: ISBN 9781513512259 (paper)

Subjects: LCSH: Financial risk management—Europe. | Housing-Prices—Europe.

Classification: LCC HD61.A74 2019

The Departmental Paper Series presents research by IMF staff on issues of broad regional or cross-country interest. The views expressed in this paper are those of the author(s) and do not necessarily represent the views of the IMF, its Executive Board, or IMF management.

Publication orders may be placed online, by fax, or through the mail: International Monetary Fund, Publication Services P.O. Box 92780, Washington, DC 20090, U.S.A.

Tel. (202) 623-7430 Fax: (202) 623-7201

E-mail: publications@imf.org www.imfbookstore.org www.elibrary.imf.org 


\section{Contents}

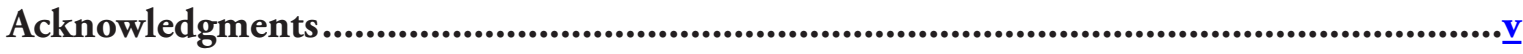

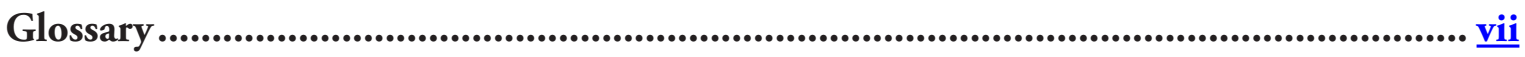

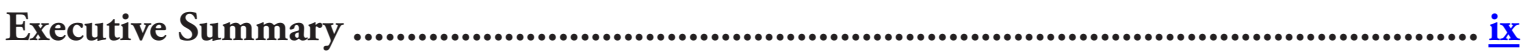

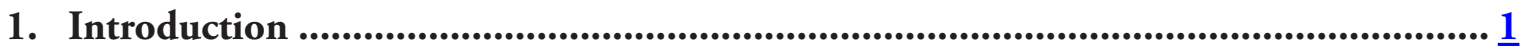

2. Literature Review.............................................................................................. 5

3. Macroprudential Measures Implemented in Europe in Recent Years......................... $\mathbb{Z}$

4. Country Experiences and Effectiveness of MaPPs................................................. 13

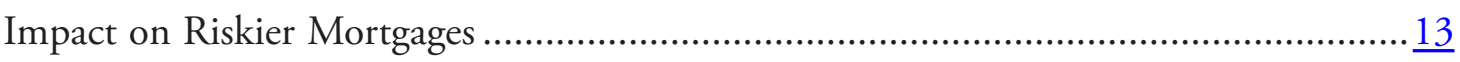

Impact on House Prices and Credit Growth ................................................... 16

5. Circumvention .......................................................................................... 21

Circumvention through Nobank Loans ............................................................. 21

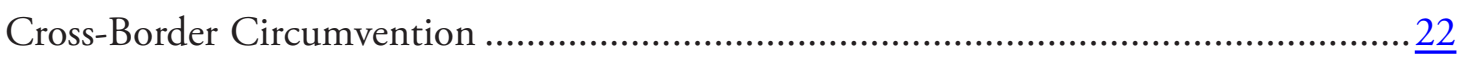

6. Macroprudential Policies and Housing Sector Policies......................................... 25

7. Balancing Financial Stability and Housing Affordability........................................ 29

8. Conclusion...................................................................................................... $\underline{33}$

References....................................................................................................... $\underline{35}$

Box

Box 1. The Impact of MaPPs in Norway and Sweden—Counterfactual Analyses ........... 19

Figures

Figure 1. Real House Prices.............................................................................

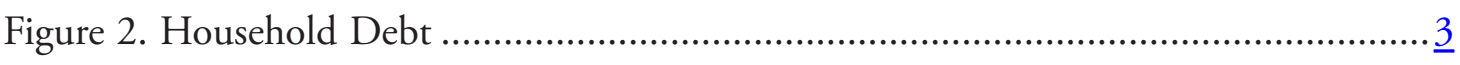

Figure 3. Frequency of Selected MaPP Measures by Reported Intermediate Objectives... $\underline{3}$

Figure 4. Number of Measures and Change in House Prices ........................................

Figure 5. Number of Measures and Change in Household Credit ................................ $\underline{4}$

Figure 6. Adoption of Macroprudential Measures by Region....................................... $\underline{8}$

Figure 7. Adoption of Key Macroprudential Measures.................................................... 2

Figure 8. Residential Housing Loan-to-Value Ratio, in Domestic Currency …............... 10 
Figure 9. Residential Housing Debt-Service-to-Income Caps, in Domestic Currency.... $\underline{10}$

Figure 10. Share of High LTV Loans in Selected Countries........................................ 17

Figure 11. MaPPs, Household Credit Growth, and House Prices in

Selected Countries.................................................................................. 18

Figure 12. The Impact of MaPPs in Norway and Sweden-Counterfactual Analyses .... $\underline{20}$

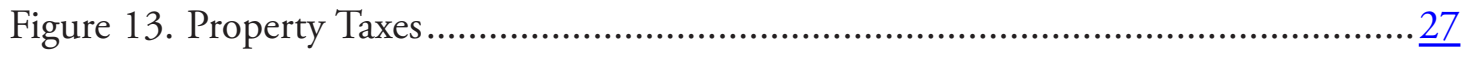

Figure 14. Price-to-Income and Price-to-Rent Ratios........................................... $\underline{30}$

\section{Tables}

Table 1. Property Tax Reforms That Were Implemented, Legislative or Announced

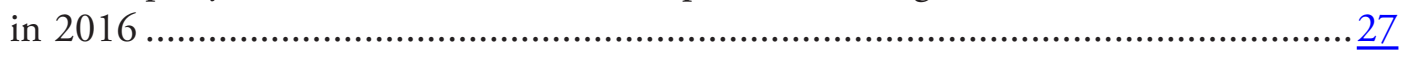

Table 2. Housing Policy Programs Surveyed by OECD ............................................ 


\section{Acknowledgments}

This IMF Departmental Paper was completed under the overall guidance of Jörg Decressin and Enrica Detragiache. The authors are grateful for comments and suggestions from participants of the IMF European Department seminar; the 12th Edition of the Seminar on Financial Stability Issues of the National Bank of Romania, held in Sinaia, Romania, November 14-17, 2018; and the European Systematic Risk Board-European Central BankIMF workshop held October 31, 2018, on the topic of a macroprudential framework. The authors would also like to thank Hannah Jung and Ben Park for formatting services. Thanks are also due to [__ $[$ ] of the Communications Department for leading the editorial and production process. 
This page intentionally left blank 


\section{Glossary}

CB capital conservation buffer

CCB countercyclical capital buffer

CESEE Central, Eastern, and Southeastern Europe

CRD capital requirements directive

CRR capital requirements regulation

DSTI debt service-to-income

DTI debt-to-income

ESRB European Systemic Risk Board

GFC global financial crisis

LTV loan-to-value

LTI loan-to-income

MaPP macroprudential policy

PTI payment-to-income

SRB systemic risk buffer

vii 
This page intentionally left blank 


\section{Executive Summary}

Recent years have seen an increasing use of macroprudential policies (MaPPs) in Europe. Since the global financial crisis, many European countries have implemented macroprudential frameworks and tools, producing an expanding body of empirical research on their effectiveness. In part, the goal of this research is to evaluate the effectiveness of macroprudential policy. This paper discusses how MaPPs have been used in Europe to address risks from the housing market and growing household indebtedness. It also documents developments in riskier mortgages, as well as house prices and credit related to the adoption of MaPPs.

Macroprudential policy in Europe aligns with the objective of limiting systemic risk, namely the risk of widespread disruption to the provision of financial services that is caused by an impairment of all or parts of the financial system and that can cause serious negative consequences for the real economy.

The paper presents evidence suggesting that MaPP implementation successfully limited systemic risk that could emerge from riskier mortgages and helped to build resilience. That said, many European countries' experiences have not yet spanned a full financial cycle, so any ensuing lessons and empirical evidence remain tentative. Overall, the findings suggest that borrower-based measures, supported by lender-based measures, helped limit the share of riskier mortgages. However, results are more mixed as to the ability of MaPPs to contain house prices and overall credit growth against the backdrop of still-accommodative monetary policy and other factors. This trend supports the notion that macroprudential policies are mainly aimed at strengthening resilience and containing systemic financial risks, rather than steering house prices and overall credit growth. Further, the wide range of institutional arrangements and policies being adopted across countries suggests that there is no one-size-fits-all approach.

ix

(C)International Monetary Fund. Not for Redistribution 
The paper also notes that macroprudential policy effectiveness in influencing house prices through credit should be assessed in the context of other policies affecting house prices. House prices are a function of many drivers, such as supply of land, zoning, tax policy, etc. It should be also noted that to the extent that MaPPs are effective in contributing to reducing housing price growth, the reduction in price will come about via a reduction in demand, as MaPPs make (some) mortgages more expensive. To protect affected households, policymakers can strengthen various policies that promote housing affordability. 


\section{Chapter}

\section{1 introduction}

Many European economies are experiencing continued or renewed housing booms, accompanied by rising household indebtedness (Figures 1 and 2). Housing prices have increased substantially across Europe over the past few years. Both of these demand factors (for example, growing household incomes and wealth, rising population, migration, lower interest rates, availability of credit) supply, policy, and structural factors (for example, supply responsiveness, tax incentives for home ownership and debt financing, and rental market regulations) are the source of the observed behavior of house prices. ${ }^{1}$ Higher house prices have been accompanied in some countries by lower housing affordability and rising household debt. Accommodative monetary policy in most countries is expected to be removed slowly, implying that low interest rates will remain an important driver of high house prices for some time. These developments pose challenges and risks to financial stability.

Addressing these risks and enhancing resilience have led to the increased use of macroprudential policies (MaPPs). MaPP instruments have been introduced in many European countries since the global financial crisis (GFC). Although there are some measures (for example, stamp duties) that could directly tackle house prices, MaPPs' main objective is to tackle systemic risk by taming lending practices and/or generating buffers. The impact on prices, then, is indirect and comes from the effect of MaPPs on credit (Figure 3). In European Union (EU) countries, various capital buffer/lender-based measures aimed at increasing resilience and indirectly containing housing sector imbalances were primarily adopted from 2013, in line with the Cap-

\footnotetext{
${ }^{1}$ See Girouard and others (2006), Egert and Mihaljek (2007), Kholodilin and Ulbricht (2015), and Geng (2018).
} 


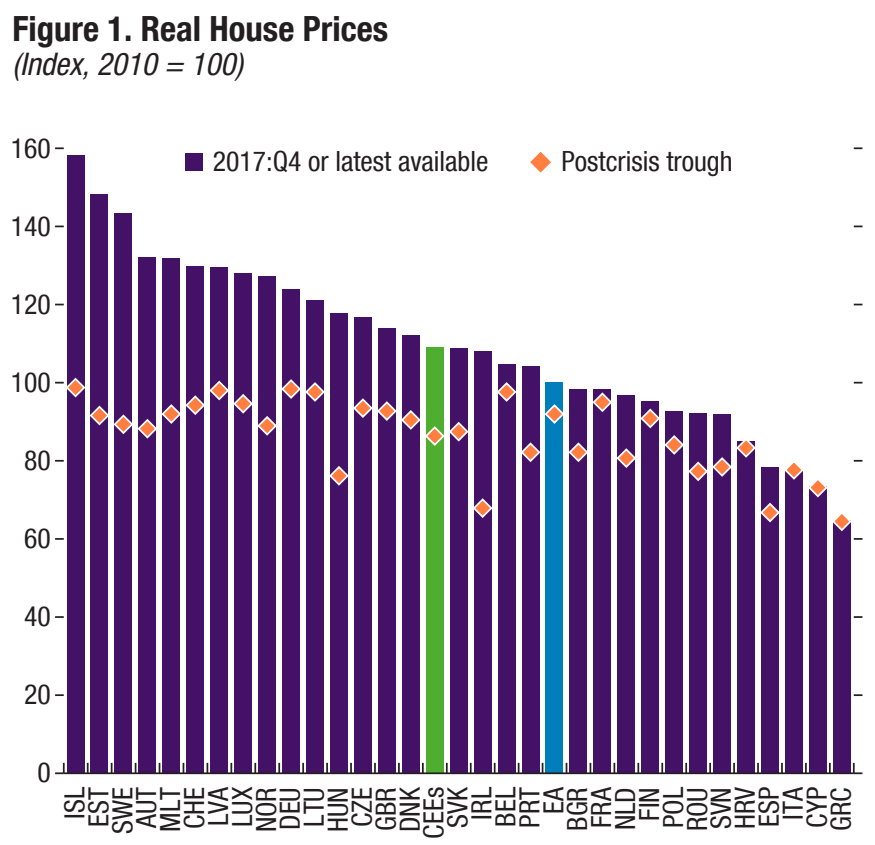

Sources: Country authorities; Haver Analytics; Organisation for Economic Co-operation and Development; and IMF staff calculations.

ital Requirements Directive (CRD IV). ${ }^{2}$ Several countries also introduced loan origination (or borrower-based) measures. While MaPPs were adopted with varying objectives, in general countries with larger post-GFC increase in house prices and household debt tended to adopt more MaPPs (Figures 4 and 5).

Implementation of MaPPs is challenging. Many countries are facing challenges with the adequacy and effectiveness of tools-especially the recently adopted measures. In particular, there is ongoing discussion as to the intermediate objectives of MaPPs, how to assess the effectiveness of MaPPs, and the extent to which circumvention and policy spillovers can weaken the impact of MaPPs. In addition to the extent that MaPPs are effective in contributing to reducing housing price growth, they will also make housing more affordable. However, the reduction in price will come about via a reduction in demand, as MaPPs make (some) mortgages more expensive. So MaPPs may also prevent some households from becoming homeowners, though this impact can be contained by introducing in their design, for instance, exemptions for first-time buyers. The effects may be especially strong on lower-income households, and policymakers will need to strive to

\footnotetext{
${ }^{2}$ Note that such requirements are expected to phase in step-by-step from 2013 until full implementation by 2019, although many countries have opted for earlier full implementation.
} 
Figure 2. Household Debt

(Percent of household net disposable income)

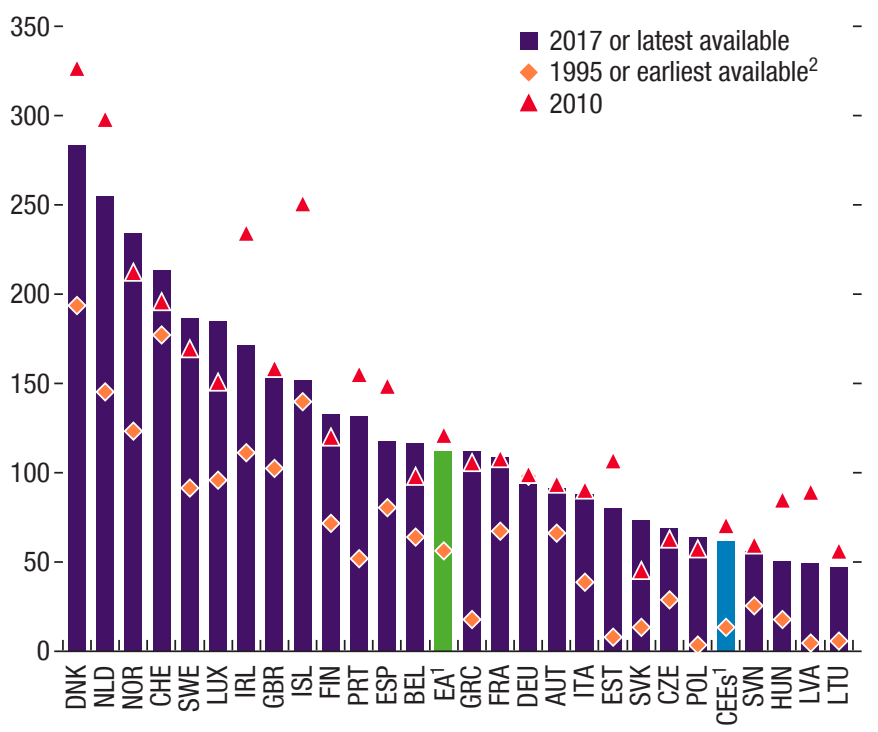

Sources: Organisation for Economic Co-operation and Development; and IMF staff calculations.

Note: $\mathrm{CEE}=$ Central and Eastern Europe; $\mathrm{EA}=$ earliest available. Country

acronyms are International Organization for Standardization (ISO) codes.

${ }^{1}$ Due to data availability, CYP and MLT are excluded for EA average, and BGR,

HRV, and ROU are excluded for CEE.

${ }^{2}$ Earliest available dates: IRL: 2001; LUX: 1999; ESP: 1999.

Figure 3. Frequency of Selected MaPP Measures by Reported Intermediate Objectives (Number of measures)

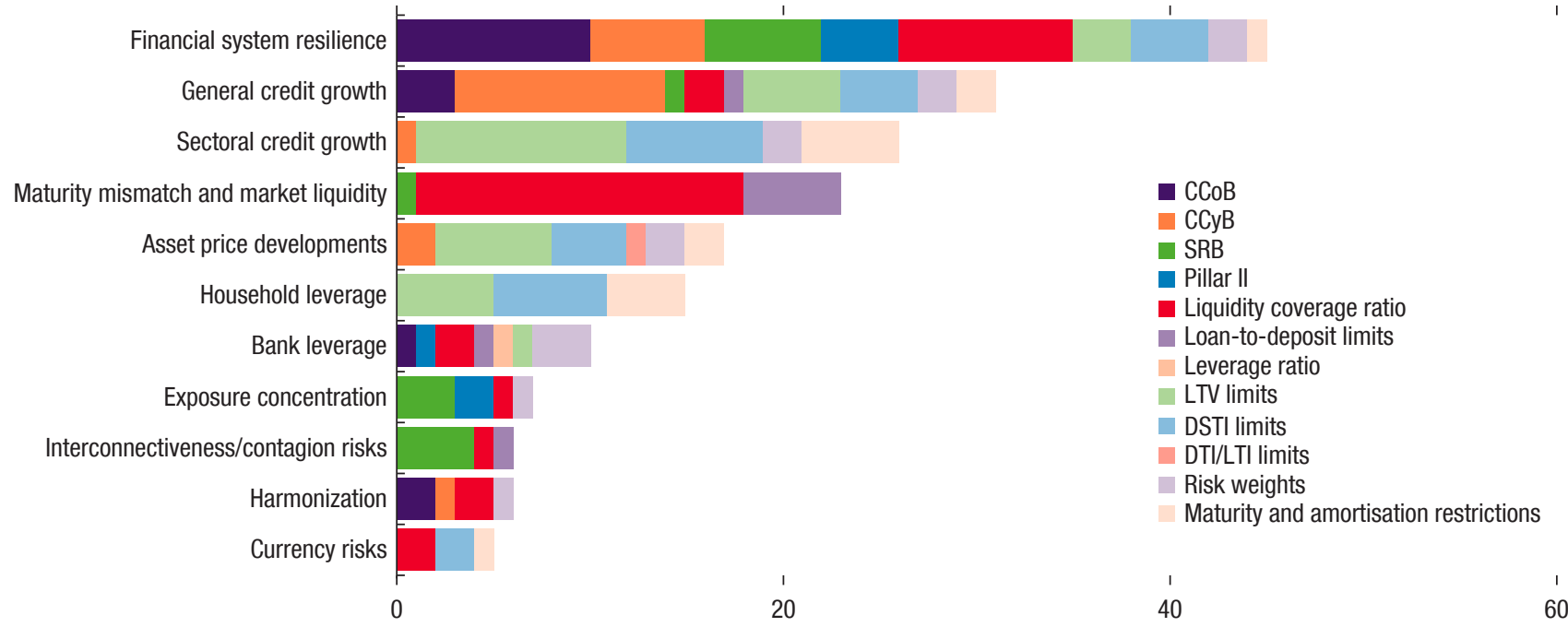

Sources: ECB = ???; European Systemic Risk Board; and IMF staff calculations.

Note: $\mathrm{CCoB}=$ Capital Conservation Buffer; CCyB = Contercyclical Capital Buffer; DSTI = Debt Service-To-Income ratio; DTI = Debt-To-Income ratio; LTV = Loan-To-Value ratio; SRB = Systemic Risk Buffer. 
Figure 4. Number of Measures and Change in House Prices ${ }^{1}$

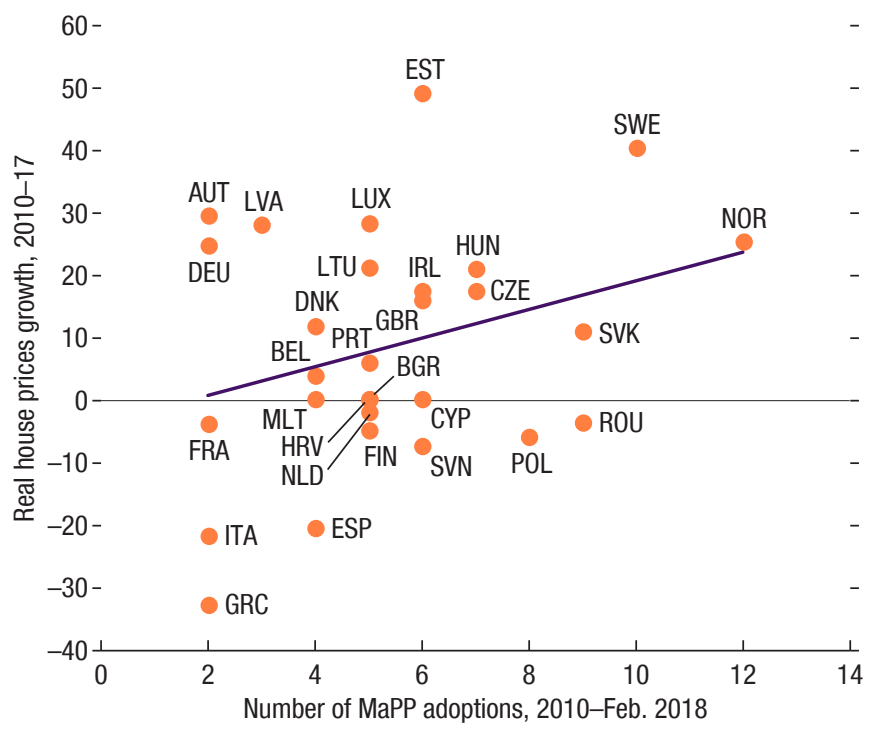

Sources: European Systemic Risk Board; Eurostat; Organisation for Economic Cooperation and Development; and IMF staff calculations.

Note: Country acronyms are International Organization for Standardization (ISO) codes.

${ }^{1}$ Comparability of number of policies implemented across countries might not be possible in all cases since some countries implement

MaPP as packages, for example, Denmark.
Figure 5. Number of Measures and Change in Household Credit ${ }^{1}$

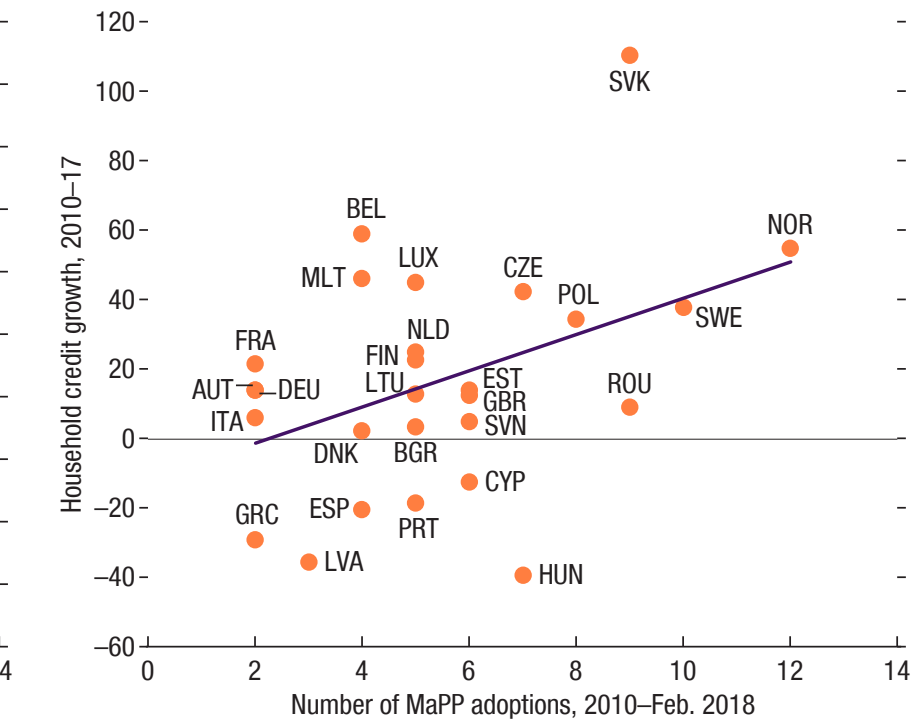

Sources: European Systemic Risk Board; Eurostat; Haver Analytics; and IMF staff calculations.

Note: Country acronyms are International Organization for Standardization (ISO) codes.

${ }^{1}$ Comparability of number of policies implemented across countries might not be possible in all cases since some countries implement MaPP as packages, for example, Denmark.

balance policies for financial stability with those aimed at promoting housing affordability.

With this background in mind, this paper informs our policy advice. This paper tracks the broader use of MaPP tools in Europe after the GFC. The main objective is to assess the effectiveness of MaPP policies and to draw on the experience of a sample of European economies to explain why some policies have been more or less effective. The case-study countries include Bulgaria, Czech Republic, Denmark, Estonia, Hungary, Iceland, Israel, Latvia, Lithuania, Norway, the Slovak Republic, Sweden, and Switzerland. Chapter 2 reviews the literature. Chapter 3 takes stock of MAPPs. Chapter 4 assesses the effectiveness of applied macroprudential measures based on the case studies. Chapter 5 deals with circumventions and external factors that can hinder macroprudential policies. Chapter 6 examines housing sector policies. Chapter 7 looks into how to balance financial stability and housing affordability. Chapter 8, in conclusion, offers policy lessons. 


\section{Chapter}

\section{Lterature Review}

The challenges highlighted by the GFC have heightened policymakers' attention to MaPPs, leading to a growing literature on the subject. The GFC has reminded policymakers that traditional macroeconomic policies are less effective in managing boom-bust cycles in asset prices, including in real estate markets (Crowe and others 2013, IMF 2013a). Microprudential regulation has also proved insufficient to prevent the buildup of systemic risks leading up to the GFC. Budnik and Kleibl (2018); Vandenbussche Vogel, and Detragiache (2012); and Dimova, Kongsamut, and Vandenbussche (2016) provide detailed databases of major prudential measures adopted since the 1990s in the EU ${ }^{1}$ and Central, Eastern, and Southeastern European (CESEE) countries. $^{2}$ They show that an increased number of European countries developed or strengthened their macroprudential toolkits since the GFC. They also show that new EU member states have on average been more active users of macroprudential policy, both in terms of frequency and diversity of tools than the EU15.

MaPPs appear to have been useful in preventing the buildup of systemic risk. Herzberg and Watson (2014), IMF (2011a, 2013b), and He and others (2016) point to favorable effects of borrower-based tools - loan-to-value (LTV) and debt-to-income (DTI) caps-on house prices and, in some cases, the associated credit growth. Together with caps to credit growth, limits to foreign currency lending, reserve requirements, dynamic provisioning, and countercyclical capital requirements, they also seem to reduce the procyclicality of credit and/or bank leverage (Lim and others 2011). Measures that effectively build resilience during the upturn through the accumulation of buffers in bank balance sheets, such as capital-based tools, contribute to a softer credit crunch during downturns, see IMF (2013b) band Claessens, Ghosh, and Mihet (2013). 
The MaPP literature has been mostly tilted toward studying the effectiveness of demand-side measures. Early studies by Igan and Kang (2011) and Craig and Hua (2011) point to the successful implementation of LTV and DTI caps in Korea and Hong Kong SAR in the late 2000s, which limited house price acceleration and the number of real estate transactions, even if total mortgage lending seems unaffected. Nevertheless, using a large panel data set (57 countries), Kuttner and Shim (2016) conclude that the link between most MAPP measures — including LTVs — and house prices is not empirically robust, supporting similar findings by Vandenbussche, Vogel, and Detragiache (2012) in CESEE countries. Instead, Kuttner and Shim (2016) find that debt service-to-income (DSTI) caps are the most consistently effective tool in curbing housing-related credit growth. The effectiveness of DSTI limits (and LTVs) in containing household credit growth is also documented by Dimova Kongsamut, and Vandenbussche (2016) for a few Southeastern European countries.

Recent studies find more evidence for the effectiveness of MaPPs. For instance, Poghosyan (2019) provides evidence on how borrower-based measures (such as LTV and DSTI) affect house prices and credit growth in a sample of $28 \mathrm{EU}$ countries. Unlike some evidence presented in this paper, Poghosyan (2019) finds that the borrower-based measures are generally effective in curbing house prices and credit growth. Alam and others (2019) use the latest macroprudential measures survey conducted by the IMF (covering 134 countries from January 1990 to December 2016) to posit that loan-targeted instruments have a significant impact on household credit.

Other empirical studies, however, found that capital-based measures dampen house price inflation and strengthen banks resilience. They thereby avert a credit crunch during busts. For CESEE countries, Vandenbussche, Vogel, and Detragiache (2012) conclude that only minimum capital adequacy ratios and changes in marginal reserve requirements on foreign funding or linked to credit growth have restrained house price inflation in the last decades. The three types of measures have a significant impact when tightened; however, when loosened only the easing of the minimum capital adequacy ratio has a relevant impact. Consistently, IMF (2013b); Claessens, Ghosh, and Mihet (2013); and Aiyar, Calomiris, and Wieladek (2014) provide cross-country evidence that capital-based tools can support credit growth during downturns by building up resilience during the upturn.

Some studies investigate effectiveness in the context of closely integrated economies. Evidence related to cross-border or cross-sector spillovers and leakages from macroprudential policies is provided in different studies, notably in the context of closely integrated EU members, see for example, Ahnert and others 2018; Forbes and others 2017; Aiyar, Calomiris, and Wieladek 2014; and Auer and Ongena 2016. 


\section{Chapter}

\section{Macroprudential Measures Implemented in Europe in Recent Years}

The application of MAPPs across European countries varies significantly (Figure 6). Central and Eastern European countries are among the most active in applying MAPPs both in terms diversity and intensity of measures. Some major economies such as France, Germany, and Italy employ few macroprudential measures. Among borrower-based measures, LTV caps are the most common, with stress/sensitivity tests and DSTI caps used in slightly more than one-quarter of cases and DTI/loan-to-income (LTI) caps adopted in only five countries. Both LTV and DSTI were adopted the earliest in 2003 for Cyprus and 2011 for Lithuania and Romania, while implementation of DTI/LTI caps is a more recent phenomenon. Most countries that adopted DSTI caps are Central and Eastern European countries (excluding Cyprus and Portugal); the five countries with DTI/LTI caps largely are spread across Western and Eastern Europe. Although the capital conservation buffer has been adopted by all, the systemic risk buffer is used by about one-half of countries, and only a handful of countries have applied non-zero countercyclical buffers.

The design of policy instruments differs across countries, reflecting countries' circumstances and policy objectives (Figure 7):

- LTV caps (Figure 8). As of July 2018, 19 European countries have LTV caps ranging from 35 to 100 percent, but most between 60 to 95 percent. In general, caps are higher on primary residences (Cyprus); for first-time buyers (Finland and Ireland); or for mortgages with collateral, guarantees, or insurance (Estonia, Latvia, Poland, and Romania). Mortgages in foreign currencies (Hungary, and Romania) or for non-primary residences in the capital city (Norway) are subject to lower caps. Since adoption, LTV caps have been tightened in the Czech Republic, the Netherlands, Norway, Poland, and Slovakia. 
Figure 6. Adoption of Macroprudential Measures by Region (Share of countries adopting the measures)

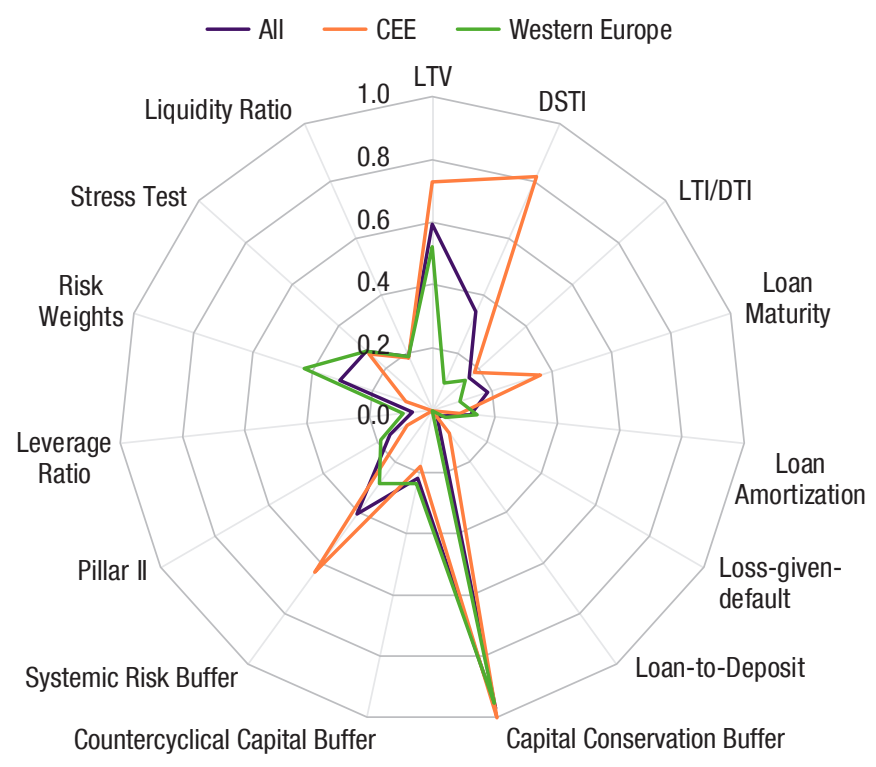

Sources: European Systemic Risk Board Database; and IMF staff calculations.

- DTI/LTI and DSTI caps (Figure 9). As of July 2018, 15 countries in the sample have imposed either DTI/LTI or DSTI cap (except for Slovakia, which adopted both LTI and DSTI caps). DSTI caps vary by borrowers' income level (Czech Republic, Hungary, Poland, Portugal, Slovakia, and Slovenia), loans with different currency denomination (Cyprus, Hungary), LTV ratio (Lithuania), or interest fixation period/debt serving frequency (Hungary, and Slovakia). Romania's DSTI caps are determined by scenario analysis that consider currency, interest rate, and income risks. The DTI (Norway) or LTI (Czech Republic, Ireland, Slovakia, and UK) caps are calibrated between 3.5 (Ireland) to 8 (Czech Republic, Slovakia) with exemption limits ranging from 8 (Oslo, Norway) to 20 (Ireland, Slovakia) percent of newly approved loans. However, it is hard to compare the magnitudes across countries due to differences in the coverage of the measure (for example, overall debt vs. a specific loan, and gross income vs. net disposable income vs. certified income) and varying degree of exemptions allowed.

- Capital requirements. So far, 16 out of 32 countries have adopted the full capital conservation buffer of 2.5 percent of risk-weighted asset, whereas others are phasing in step-by-step. All countries have introduced the countercyclical capital buffer, but only the Czech Republic, Iceland, Norway, Slovakia, Sweden, Switzerland, Lithuania, and UK have non-zero buffers of 0.5 to 2 percent. Systemically important banks are subject to additional 
Figure 7. Adoption of Key Macroprudential Measures

(As of July 2018; Number of countries adopting the measures)

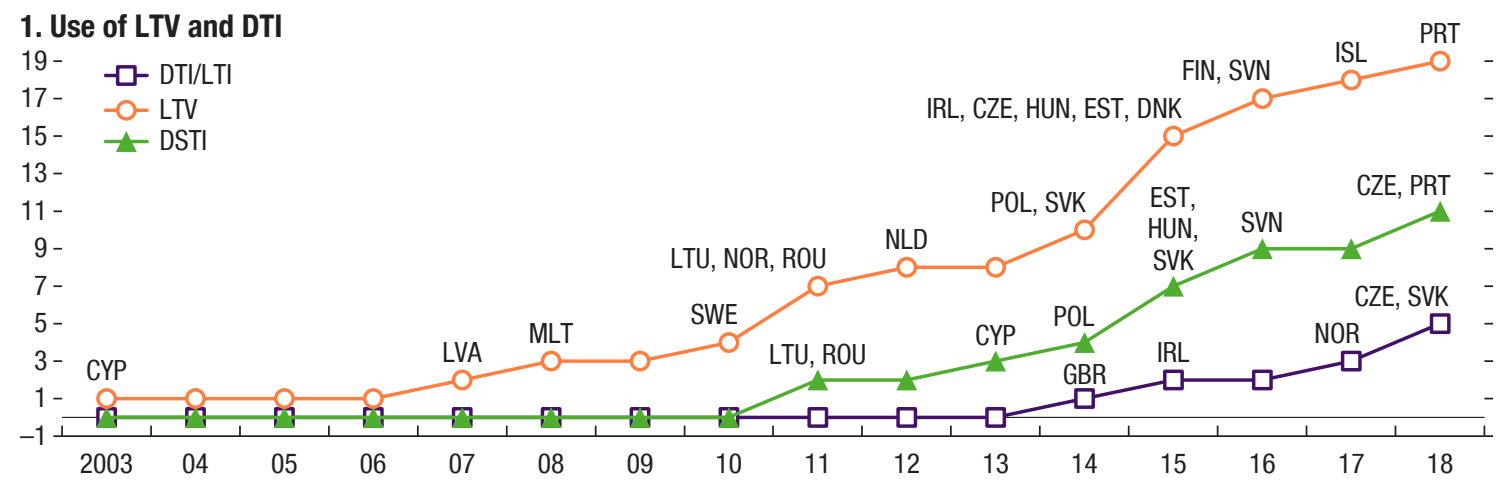

\section{Use of Loan Amortization and Maturity Requirement}

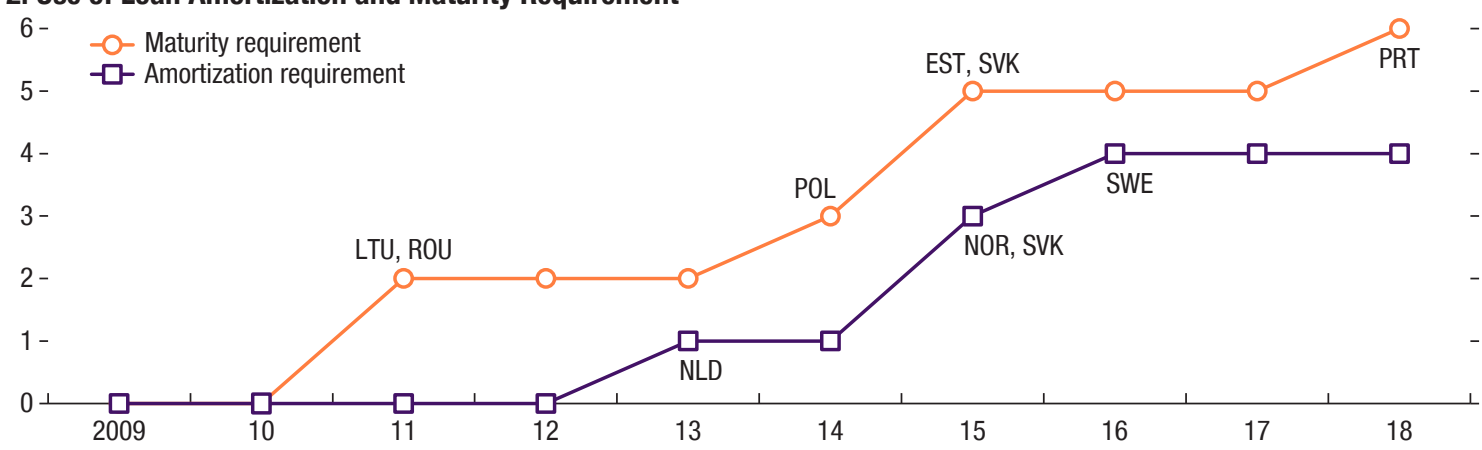

3. Use of Capital Buffers ${ }^{1}$

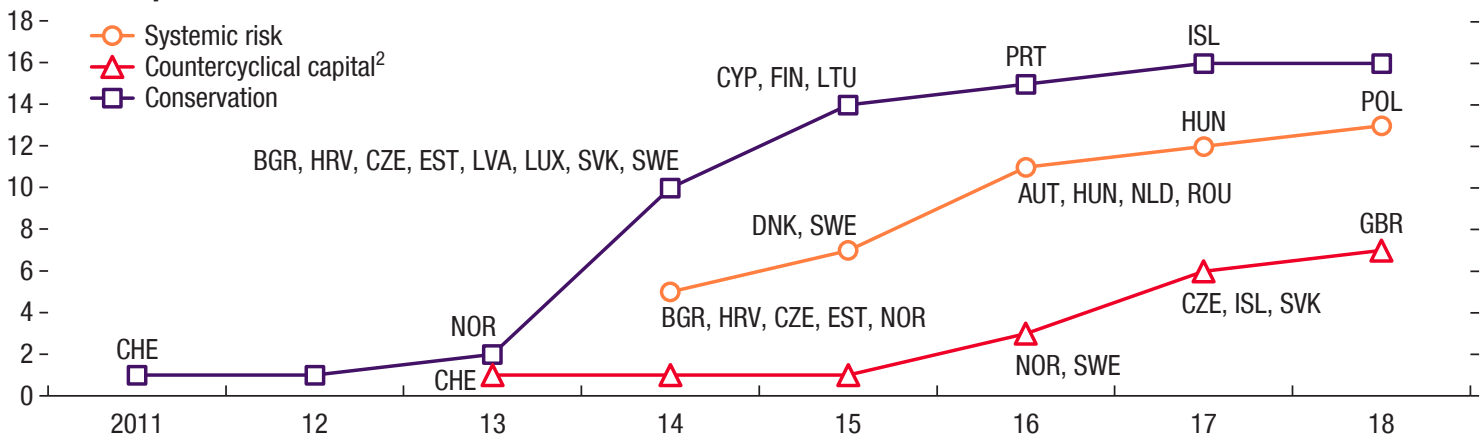

Sources: European Systemic Risk Board Database; and IMF staff calculations.

Notes: Country acronyms are International Organization for Standardization (ISO) codes.

${ }^{1}$ Countries with full implementation of capital conservation buffer of 2.5 percent are shown in the figure. The rest have adopted the measure, which is gradually phasing in. All countries have adopted countercyclical buffers, but only the shown countries have adopted non-zero buffers. Finland adopted SRB in June 2017, but it is only to be activatedin July 2019.

${ }^{2}$ At the end of 2018, Luxembourg adopted a countercyclical capital buffer of 0.25 percent to be actived on 1/1/2020. 
Figure 8. Residential Housing Loan-to-Value Ratio, in Domestic Currency (Percent)

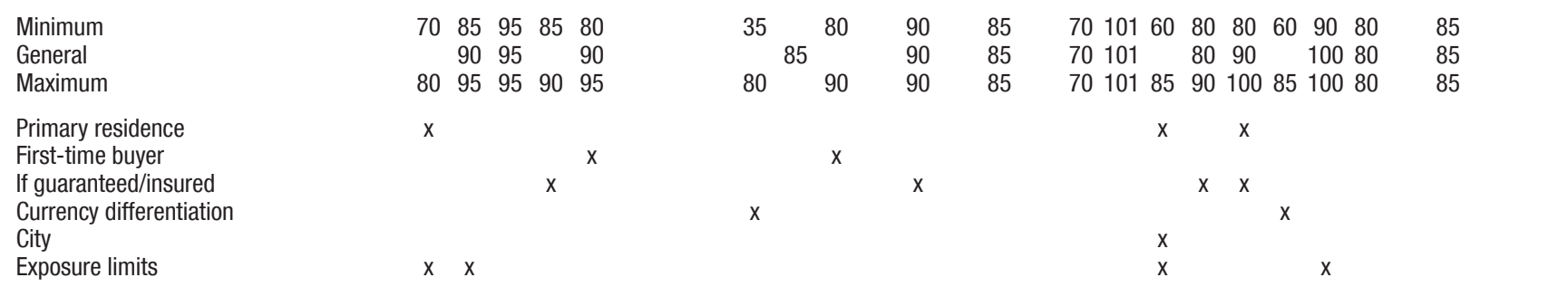

Sources: European Systemic Risk Board Database; and IMF staff calculations.

Figure 9. Residential Housing Debt-Service-to-Income Caps, in Domestic Currency ${ }^{1}$ (Percent)
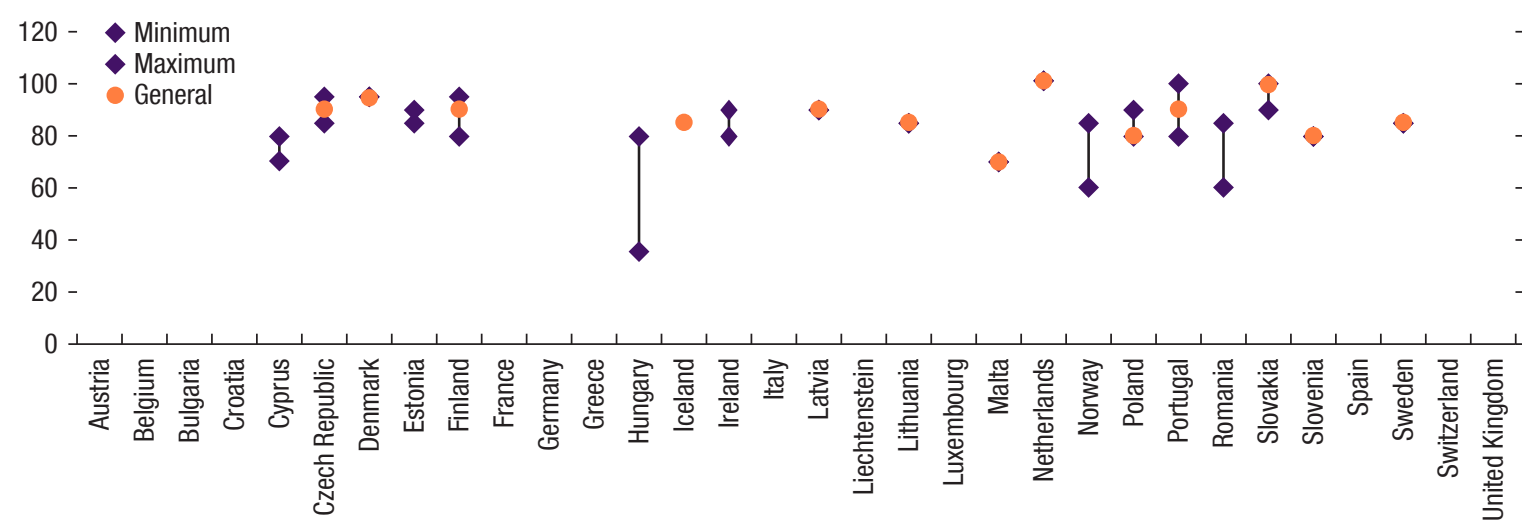

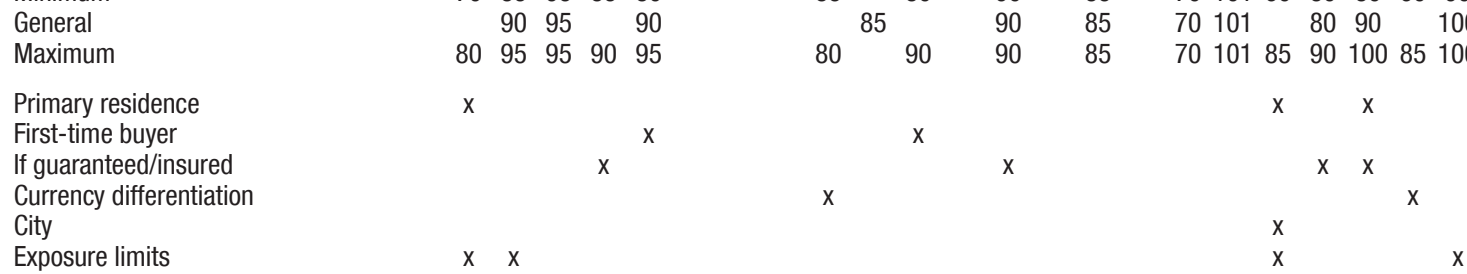

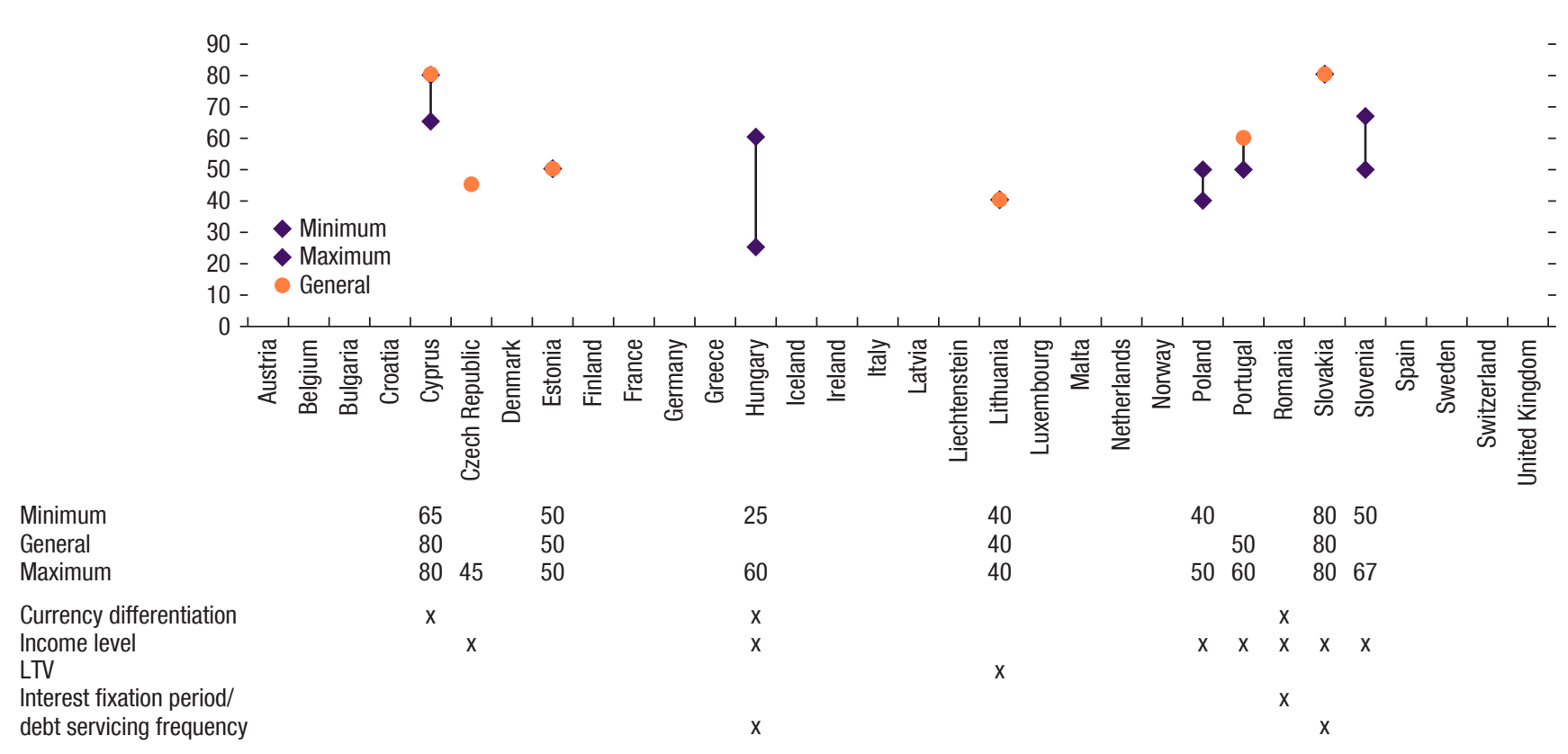

Sources: European Systemic Risk Board Database; and IMF staff calculations.

${ }^{1}$ For the Netherlands, data are unavailable. LTV, DSTI, and amortization measures are not aimed at banks and are thus in essence not exposure-based. However, as they only apply to Dutch mortgages de facto, they only apply to domestic exposures for Dutch banks.

(See ECB MaPPeD database). 
capital requirements that vary across systematically important financial institutions by systemic importance (Austria, Croatia, Czech Republic, Denmark, Hungary, Iceland, Lithuania). ${ }^{1}$ A total of 13 countries have adopted the systemic risk buffer (SRB). Some countries have also imposed sectoral risk weight floors on commercial real estate (Croatia, Finland, Ireland, Norway, Romania, Sweden, $U K)^{2}$ and residential mortgages (Belgium, Croatia, Luxembourg, Norway, Slovenia, Sweden). Among this group, Sweden and Norway have applied most of the existing balance sheet measures, and their required aggregate capital buffers are among the highest.

\footnotetext{
${ }^{1}$ Bulgaria, Estonia, the Netherlands, Norway, Romania, Slovakia, and Sweden apply one buffer to all banks; Hungary vary systemic risk buffers by the institution's exposure to commercial real estate loans.

${ }^{2}$ In the case of the UK, the Prudential Regulation Authority set certain criteria, based on EU law, that make it harder for firms to use the preferential risk weight of 50 percent for CRE [please spell out CRE] exposures. Instead, firms have to apply the default risk weight for CRE if they don't meet these criteria.
} 
This page intentionally left blank 


\section{Chapter}

\section{Country Experiences and}

This section provides an assessment of the effectiveness of MaPPs by documenting their impact on riskier mortgages, primarily through eight case studies that analyze the evolution of the specific target variables these measures are meant to affect, as well as the dynamics of house prices and credit.

\section{Impact on Riskier Mortgages}

- Czech Republic. Macroprudential measures included lender-based measures (capital conservation buffer [CB] at 2.5 percent, countercyclical capital buffer [CCB] at 1 percent, and SRB ranging within 1-3 percent) put in place since 2014, as well as a tightening of the maximum recommended LTV ratio in the first quarter of 2017. Their implementation was followed by a clear decline in the share of new mortgages with LTVs above 80 percent and an increase in those with an LTV between 70 and 80 percent. This outcome, however, should be assessed carefully as it may have been partly offset by a more favorable valuation of collateral. Meanwhile, debt-servicing and loan-to-income ratios did not show a meaningful improvement over the period.

- Denmark. Restrictions on the borrowing capacity of households relative to their disposable income and their interest-rate sensitivity have been in effect since 2014. A consumer protection clause was introduced in 2015 mandating at least 5 percent down payment for residential estate purchases, translating into a 95 percent maximum LTV. After these measures, the share of new mortgages with an LTV above 95 percent declined markedly, while the share of mortgages with an LTV between 80 and 90 percent declined slightly. These measures were supplemented by guidelines on good business practices for housing credit (2017), which helped increase the resilience of borrowers, for instance by promoting a higher share of 
fixed-rate mortgages, and by limiting excessive leverage by households with lower incomes.

- Hungary. Since the GFC, the authorities have been implementing a range of borrower-based MaPPs and the share of new housing loans with an LTV ratio over 70 percent more than halved, to about 30 percent in the first half of 2017. In March 2010, 75/60/45 percent maximum LTV ratios were adopted for mortgage loans denominated in, respectively, local currency, euros, and other currencies. In early November 2014, the central bank and the Bank Association agreed on a fast and orderly conversion of foreign exchange mortgage loans to local currency, to reduce the exposure of household balance sheet to exchange rate risk. Beginning in 2015, the maximum LTV ratios were, respectively, 80, 50, and 35 percent and were complemented by payment-to-income (PTI) ratios (akin to DSTI). For borrowers with a net monthly income below HUF 400,000 (about $€ 1,250)$, the PTI ratios are 50/25/10 percent. For borrowers with a higher income, the ratios are 60/30/15 percent. Effective October 2018, and to be further tightened from July 2019, the PTI ratios have been modified to encourage longer interest rate fixation periods. In April 2017, the mortgage funding adequacy ratio was introduced to ensure stable long-term funding for long-term mortgage lending. These measures - together with the central bank certified consumer-friendly housing loans introduced in 2017-have likely helped the quality and sustainability of housing loans.

- Israel. Measures included LTV caps adopted in November 2012 (75 percent for first-time buyers and 50 percent for mortgages for investment properties) and an increase in risk weights adopted in March 2013 (to 50 percent for those with an LTV ratio of 45-60 percent, and to 75 percent for those with an LTV ratio above 60 percent). The measures appear to have been effective, as the proportion of new mortgages with an LTV of more than 75 percent declined from 6 percent in October 2012 to 0.5 percent by February 2014, and the proportion of mortgages with an LTV between 60 and 75 percent also declined modestly. A significant drop in the latter in 2016 was likely due to new regulatory requirements fully implemented in 2015 as well as to fiscal measures aimed at discouraging investors' demand.

- Norway. In response to high house prices and growing household debt, the authorities implemented higher capital and liquidity requirements $(\mathrm{CB}$, CCB, SRB, domestically systemic important institutions, and leverage ratio) in 2013-17 and borrower-based measures targeted to the mortgage market (LTV limit, DTI limit, amortization requirements). Following the implementation of the LTV cap, the share of new loans with an LTV ratio above 85 percent has declined. The DTI measure that came into force from the beginning of 2017 also led to a decline in the share of 
new mortgages with a DTI of more than 500, from 9 percent in 2016 to 2 percent in 2017.

- Slovakia. Several MaPPs have been introduced to contain increasing household indebtedness, high concentration of residential mortgages in bank portfolios, and rapidly growing house prices. LTV measures implemented in 2014 and the recent decision to set the CCB to 0.5 percent have helped to improve lending standards and credit quality. Specifically, the share of new loans with an LTV ratio of more than 90 percent fell to below 20 percent by the second quarter of 2015 and continued to decline to 6.3 percent by the third quarter of 2016. The proportion of new mortgages with an LTV ratio of 80 to 90 percent initially increased but has since come down noticeably.

- Sweden. To counteract unhealthy lending practices and strengthen consumer protection, the authorities introduced a mortgage cap in 2010, mandating that new mortgage loans should not exceed 85 percent of the value of the home. The share of high-LTV mortgages declined after these measures. In addition, a study by the authorities using a difference-in-difference approach found that households limited by the mortgage cap borrowed approximately 13 percent less and purchased homes that were approximately 10 percent less expensive than what they would have otherwise done. The mortgage cap has had the greatest effect outside the metropolitan regions.

- Switzerland. Facing strong and prolonged growth in house prices, risk weights were raised for the part of a residential mortgage in excess of an 80 percent LTV ratio at the beginning of 2013. The proportion of new mortgages with an LTV ratio higher than 80 percent declined by about 5 percentage points in 2013. In addition, Switzerland was the first country in Europe to activate the CCB in 2013, targeting mortgage-backed positions secured by residential property. The buffer was set at 1 percent initially and raised to 2 percent in 2014. Following these measures, capital-constrained or mortgage-intensive banks raised their mortgage rates, and as a result, new mortgage loans were shifted to better-capitalized and less mortgage-intensive institutions.

All in all, the case studies provide some evidence that demand-side MaPPs targeted to the residential mortgage market helped curb the growth of riskier mortgages. A simple before-after comparison suggests that the introduction of borrower-based MaPPs, supported by lender-based measures, influenced the dimensions directly targeted by the measures, while their impact on house prices and overall growth was mixed. That said, a more conclusive evaluation of the effects of these policies has to await the completion of a full economic cycle. Also, some country experiences suggest that circumvention must be addressed, as discussed in Chapter 5. 


\section{Impact on House Prices and Credit Growth}

Our assessment, however, provides a more mixed picture of the impact of macroprudential measures on house prices and overall credit growth (Figures 10 and 11). Although no country has explicitly framed MaPPs to target house prices, some countries used MaPPs borrower-side measures to limit the share or riskier mortgages. And these policies indirectly affected the development of housing markets. In some countries (for example, Denmark), house price growth was not accompanied by rapid growth in bank credit. Thus, measures that targeted mortgage credit were not likely to affect house price dynamics in these countries. In addition, circumvention may have played a role in some cases, as discussed in Chapter 5.

Conclusions differs somewhat across countries. In Switzerland, following several macroprudential measures, real estate price growth and the pace of mortgage lending have gradually eased. In contrast, house prices in the Czech Republic, Hungary, and the Slovak Republic continued to grow rapidly after macroprudential measures were introduced, though the measures may have helped to contain faster increases. In Israel, house prices-which were not a MaPP target in this case-continued to rise, partly reflecting low interest rates and housing supply impediments. However, a deceleration in house prices observed since 2016 reflects a combination of proposed fiscal measures to discourage investor demand, a rise in mortgage interest rates linked to capital surcharges on mortgage lending, and market uncertainty associated with the Buyer's Price program. In Norway, the impact on house prices appears to have been only transitory. This is also in line with the recent experience of Sweden, where amortization requirements and LTV requirements curbed credit growth, but had less of an impact on house prices. Amortization requirement measures seem to have dampened house prices at least initially, but other factors, such as prospects for increased housing supply, may have also played some role. ${ }^{1}$

Further assessment using model-based approaches provides another perspective of the impact of MAPPs on credit growth and housing prices. Controlling for macroeconomic environments following Price (2014), macroprudential measures appeared to contribute to containing credit growth in Norway and Sweden (Box 1). Lack of policy action amid strengthening economic activity, demographic and housing supply pressure and other factors would have driven housing prices and credit growth to significantly higher levels (or have prevented their decline) thereby increasing financial stability risks further. Similarly, a difference-in-difference approach suggests that Sweden's implementation of a mandatory amortization requirement in 2016 encouraged households to borrow less and to buy less-expensive houses.

${ }^{1}$ Næss-Schmidt and others (2017). 


\section{Figure 10. Share of High LTV Loans in Selected Countries}

\section{Czech Republic}

\section{(Percent of new mortgage loans)}

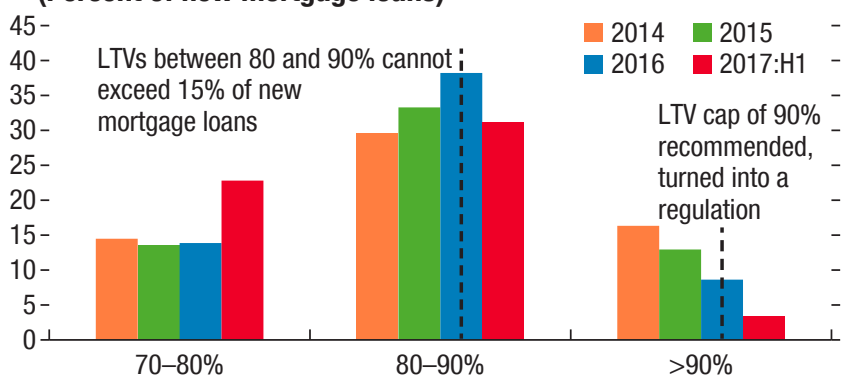

\section{Hungary}

(Percent of new mortgage loans)

$70-$

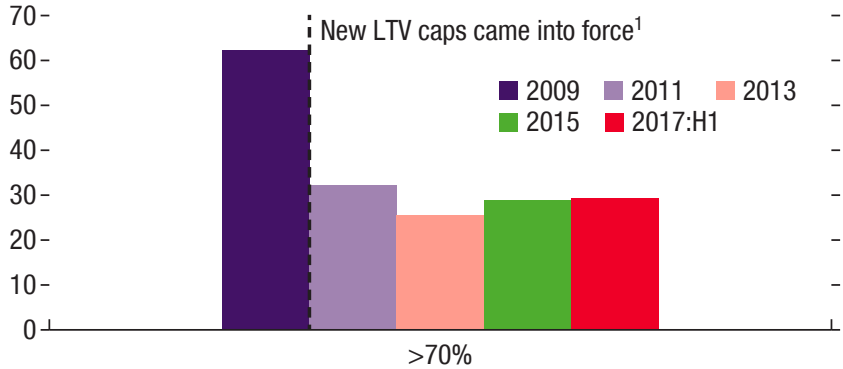

\section{Norway ${ }^{2}$}

(Percent of new mortgage loans)

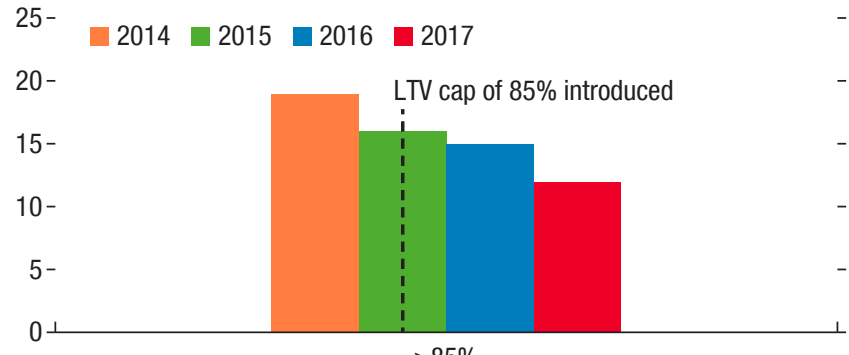

$>85 \%$

\section{Sweden}

(Percent of new mortgage loans)

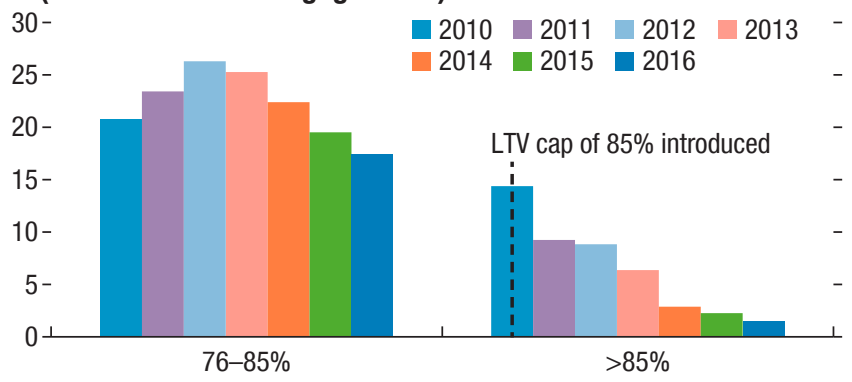

\section{Denmark}

(Percent of new mortgage loans)

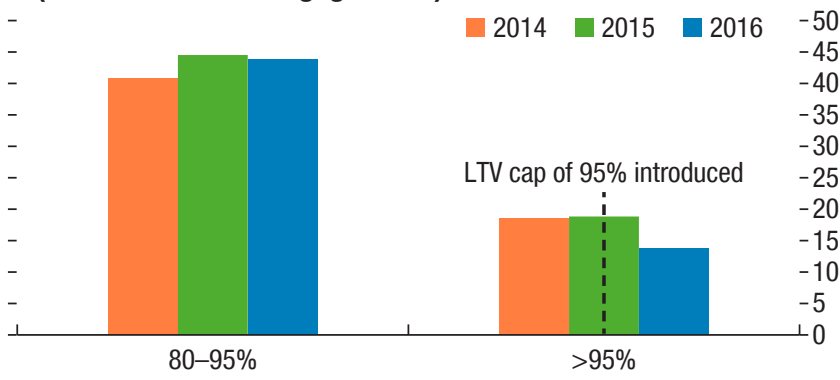

4. Israel

(Percent of new mortgage loans)

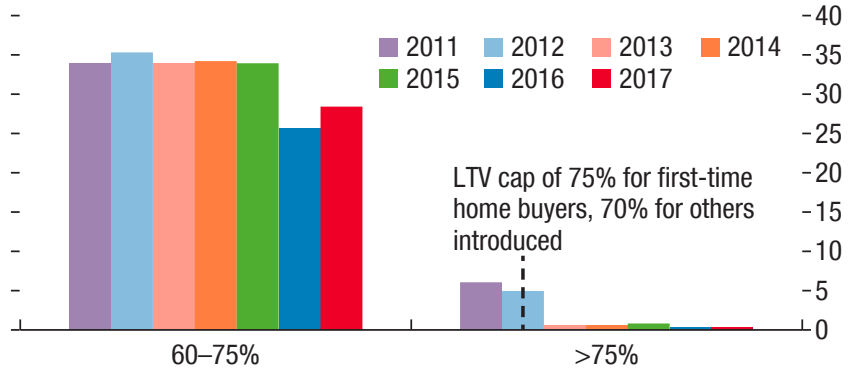

6. Slovak Republic

(Percent of new mortgage loans)

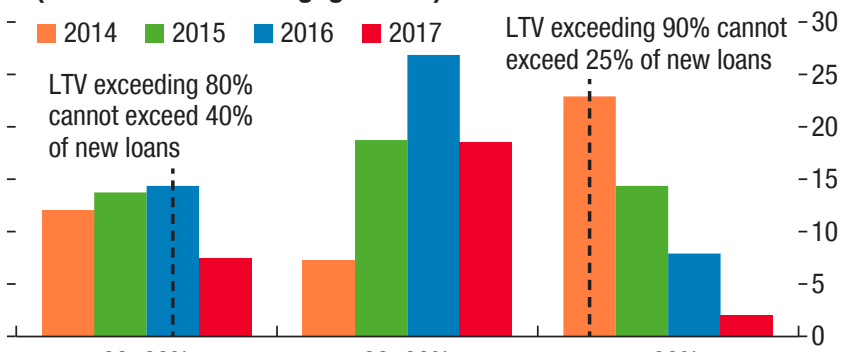

$80-89 \%$

$89-90 \%$

$>90 \%$

\section{Switzerland}

(Percent of new mortgage loans)

$2012-2013-2014-2015-2016-2017 \quad-30$

Cash down payment requirement $\longrightarrow$ Risk weight for residential -25 of $10 \%$ introduced

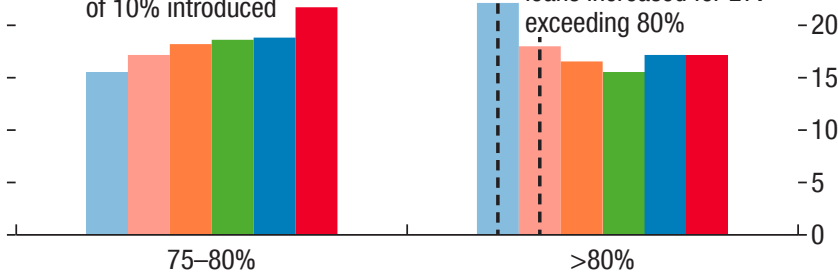

Sources: Bank of Israel; Central Bank of Hungary; Czech National Bank; Danmarks Nationalbank; Finansinspektionen; National Bank of Slovakia; the Norwegian FSA; Swiss National Bank; and IMF staff calculations.

${ }^{1}$ Effective March 2010, the following maximum LTV ratios came into force: 75 percent for retail mortgages in domestic currency, 60 percent for euros, and 45 percent for other currencies. The ratios were 5 percentage points higher on loans for residential leasing. The LTV caps on retail mortgage loans have since been adjusted to, respectively, 80 percent, 50 percent, and 35 percent. Regarding financial leases, 5 percentage points higher LTV limits can be applied.

${ }^{2}$ LTV ratio does not include additional collateral. However, the mortgage regulation allows for the use of additional collateral. 
Figure 11. MaPPs, Household Credit Growth, and House Prices in Selected Countries

Measures in 2014-15 (strengthened amortization requirement) helped to continue stabilizing credit growth, but growth of loans to household remains about at the same level as before.

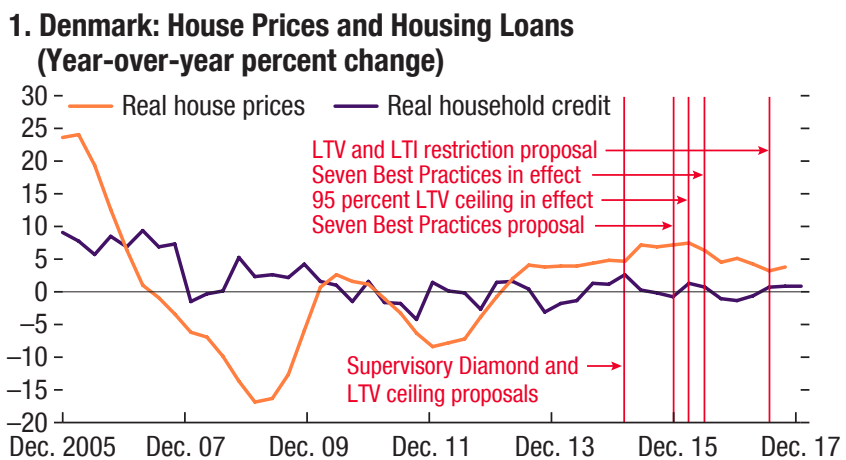

Sources: Statistics Denmark; and IMF staff calculations.

Growth rate of house prices has decelerated since late 2016, reflecting changes in the regulatory requirements since 2015 and some fiscal measures ...

\section{Israel: House Prices and Housing Loans \\ (Year-over-year percent change)}

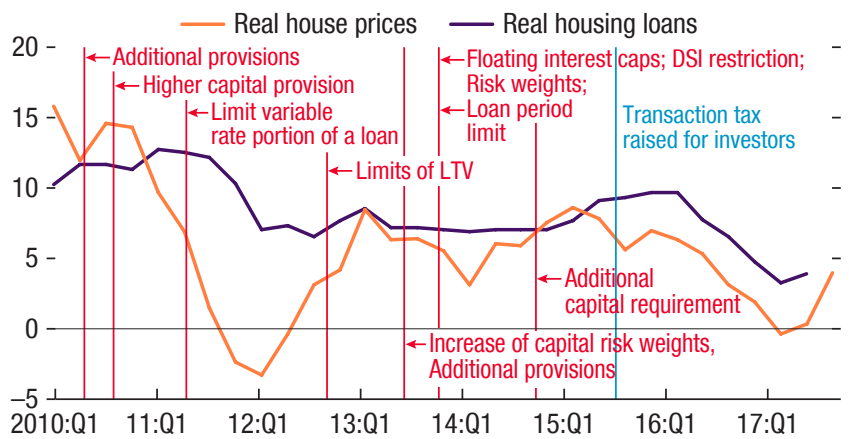

Source: Bank of Israel.

Sweden's amortization requirement measures seem to have dampened house prices at least initially, but other factors such as prospects for increased housing supply may have also played some role.

\section{Sweden: Amortization Measure Effect on Property Prices (SA, index level, in logarithm)}

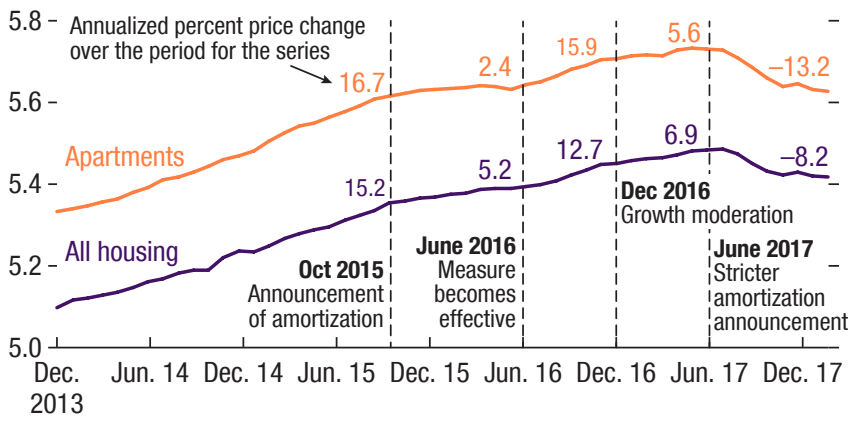

Sources: OMX Valueguard; and IMF staff calculations.
House price growth in Hungary appears to have stabilized, following the measures.

\section{Hungary: House Prices and Housing Loans} (Year-over-year percent change)

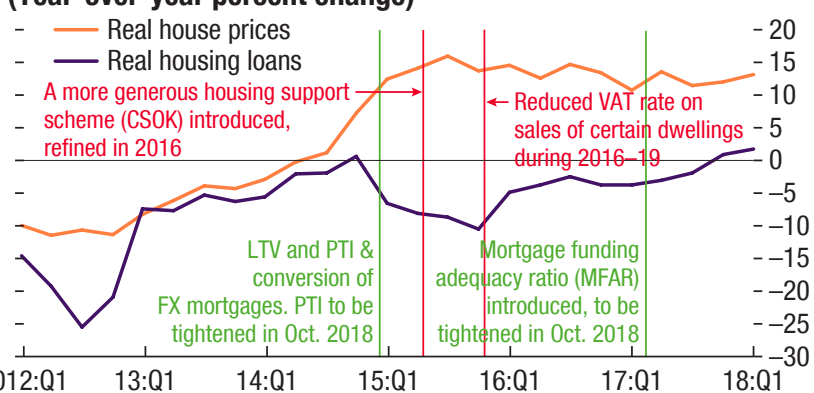

Sources: MNB, Hungarian Ministry for National Economy; and IMF staff calculations.

... while the impact of measures in Slovakia on credit growth seems to have been limited.

\section{Slovakia: House Prices and Housing Loans (Year-over-year percent change)}

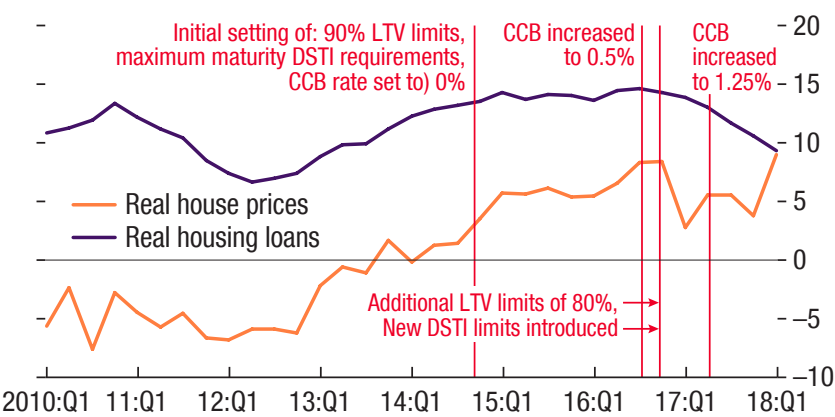

Sources: Haver Analytics; and National Bank of Slovakia.

MaPPs have had a lasting moderating effect on the level of household debt, but real estate price growth and lending have eased progressively.

\section{Switzerland: House Prices and Housing Loans} (Year-over-year percent change)

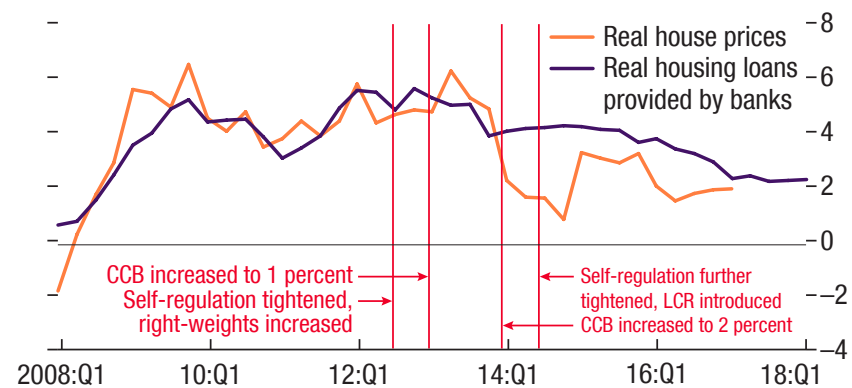

Sources: Haver Analytics; IMF Global Housing Watch; and IMF staff calculations. 


\section{Box 1. The Impact of MaPPs in Norway and Sweden-Counterfactual Analyses}

To assess the effectiveness of MaPP measures, counterfactual analysis is used to gauge the impact of MaPPs specifically targeted at the housing market on containing household credit in Norway and Sweden. We estimated the effectiveness of these measures by projecting counterfactual growth rates of household credit and house prices using data from the first quarter of 2003 for Norway, and from the first quarter of 1981 in the case of Sweden. The estimation proceeded in two steps. First, a vector autoregression model was estimated consisting of housing-specific variables (household credit growth, house price growth, housing starts/completions, house sales) and macroeconomic variables (household income growth, output gap, net immigration rate, population growth, mortgage interest rate), using data prior to the implementation of the measures. Second, based on model predictions, the dynamics of housing-specific variables were projected conditional on the actual behavior of macroeconomic variables in the periods after the measures became effective.

The analysis suggests that the household credit growth would have been higher without the measures, but statistical significance is borderline. Actual credit growth paths are found to remain below counterfactuals in both cases, with the difference becoming statistically significant at the 95 percent confidence level in Norway starting several quarters after the introduction of MaPPs. In Sweden, actual credit growth is close tobut still within - the lower bound of the confidence interval. Not surprisingly, MaPPs appear to affect house prices and household credit with delays, so over time the mitigating impact may become larger. Turning to house prices, counterfactuals are above actual values in Sweden, but not significantly so. In Norway, the difference is positive only in 2017 and the estimated confidence interval is very large. While these results are suggestive of some effect on household credit, they should be interpreted with care, bearing in mind the relatively short time since the implementation of some measures and the well-known empirical challenge in isolating the impact of policy changes from that of other intervening factors. 


\section{Box 1. The Impact of MaPPs in Norway and Sweden-Counterfactual Analyses (continued)}

Figure 12. The Impact of MaPPs in Norway and Sweden-Counterfactual Analyses

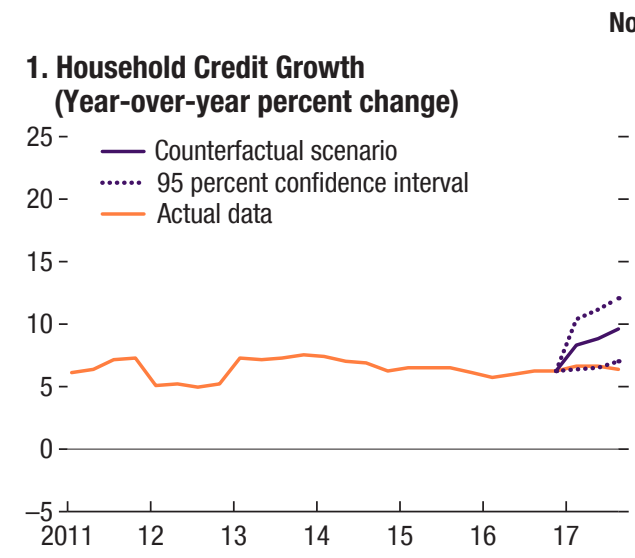

Norway

2. House Price Growth

(Year-over-year percent change)

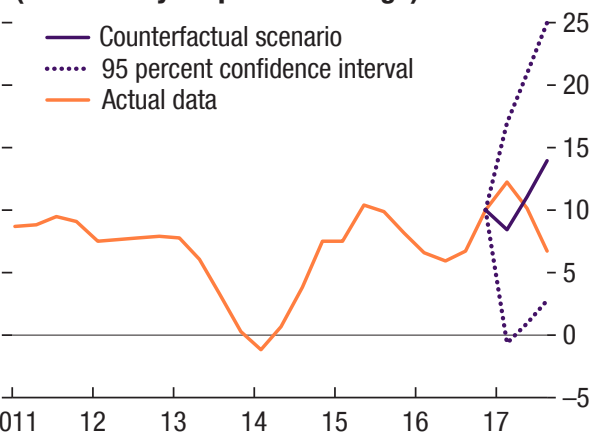

Sweden

3. Household Credit Growth

(Year-over-year percent change)

25 - _ Counterfactual scenario

20 - ...... 95 percent confidence interval

- Actual data

4. House Price Growth (Year-over-year percent change)

$15-$

$10-$

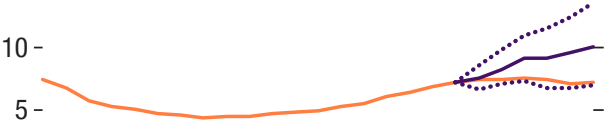

0
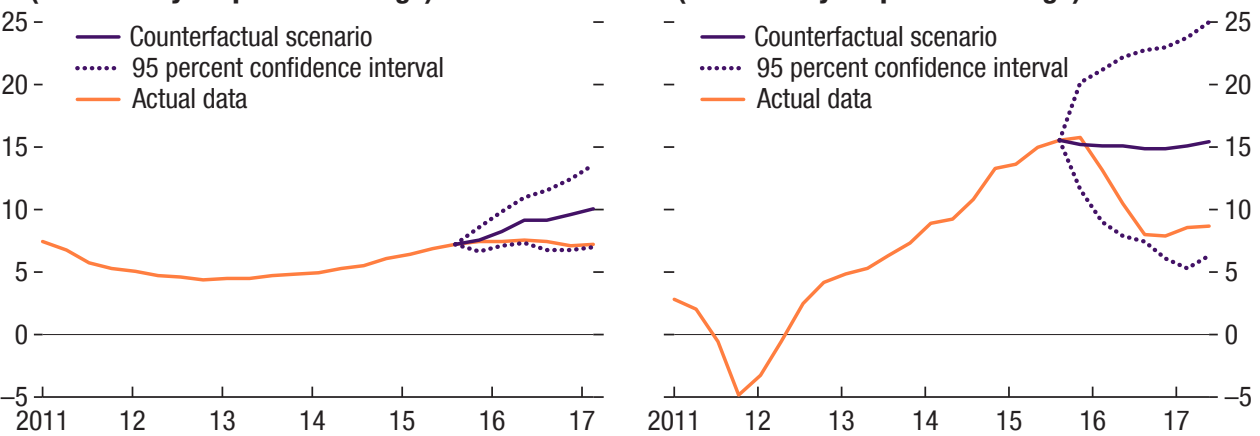

Source: IMF staff estimates. 


\section{Chapter}

\section{Circumvention}

The effectiveness of macroprudential policies may be limited by circumvention, particularly through the shadow banking system (nonbank loans) and cross-border loans. Other ways to circumvent regulations may be linked to inappropriate policy design - these approaches are not discussed in this paper.

\section{Circumvention through Nonbank Loans}

Macroprudential measures have been partly circumvented by nonbanks when nonbanks are subject to less-stringent regulation. For instance, Dimova, Kongsamut, and Vandenbussche (2016) show that some measures imposed on banks in Bulgaria and Romania to contain credit growth before the GFC were partly circumvented through loan booking with nonbank financial institutions. In Croatia, a credit growth cap was implemented on banks in 2003, but banks affiliated with leasing companies reacted by encouraging customers to take leases (IMF 2013a). Based on a data analysis of bank and nonbank credits in 40 countries, Cizel and others (2016) find evidence of a substitution effect toward nonbanks following MaPPs on banks. IMF (2014a) similarly documents that a tightening of banking regulation tends to foster nonbank activities. ${ }^{1}$

Regulatory parameters have been broadened in some jurisdictions to cover nonbanks (Annex V of IMF 2013a), but important gaps remain. In the Croatian example discussed earlier, the authorities responded by capturing the funding of leasing companies within the credit limit (IMF 2013a). Similarly, Finland, Hungary, Latvia, and the Netherlands expanded the scope of their LTV limits to cover nonbanks. Other policy responses to circumvention through nonbanks include closer cooperation with nonbank supervisors

\footnotetext{
${ }^{1}$ Buchak and others (2017) find that in the US, tightening bank regulatory constraints is associated with a significant expansion of the shadow bank market share. This expansion is supported by technological progresses.
} 
(Jacome and Mitra 2015). However, important policy gaps remain in several countries. The scope of LTV limits does not include nonbanks in some European countries (European Systemic Risk Board 2016). The FSB (2016) calls for enhancing public disclosure to help market participants understand risks related to nonbanks.

\section{Cross-Border Circumvention}

Loans financed by internationally active banks have also been a source of circumvention, particularly in the Baltic and CESEE countries. ${ }^{2}$ For instance, in Estonia macroprudential measures implemented during 2005-06 are considered to have been less effective due to cross-border borrowing from foreign banks, largely channeled through local subsidiaries and branches (Kang and others 2017; Sutt, Korju, and Siibak 2011). ${ }^{3}$ Cross-border circumvention was also experienced in Bulgaria, where risk weights were tightened on mortgages in 2005 and 2006, but credit growth remained broadly unchanged. Croatia and Poland had a similar experience (Bakker and Gulde 2010, Dimova, Kongsamut, and Vandenbussche 2016, as well as Annex I of Kang and others 2017). Kang and others (2017) find evidence of cross-border circumventions in their global sample, which is even stronger in their European sample, especially on sectoral measures (such as LTV and DTI limits). Empirical studies, such as Cerutti, Claessens, and Laeven (2015), Akinci and Olmstead-Rumsey (2015), Reinhardt and Sowerbutts (2015), and Buch and Goldberg (2017) broadly find that macroprudential tightening is associated with lower domestic credit but often with higher cross-border borrowing. ${ }^{4}$

Thus, policies for addressing circumvention should include foreign providers of financial services (IMF-FSB-BIS 2016). Reciprocity 5 is a cornerstone of the Basel-III agreement on the CCB (BCBS 2010). In the EU, the capital requirements regulation (CRR)/CRD IV mandates automatic reciprocity for the $\mathrm{CCB}$, higher real estate risk weights, stricter lending criteria, and higher minimum exposure-weighted average loss given default, while reciprocity of

\footnotetext{
${ }^{2}$ Cross-border bank loans to Central Europe rose from about 10 to 30 percent of GDP from 2002 to 2008, while those to Southeastern Europe rose from about 10 to 80 percent of their GDP (Annex I, Kang and others 2017).

3These macroprudential measures included (1) an increase in risk weights for mortgage loans from 50 to 100 percent, (2) an increase in reserve requirements from 13 to 15 percent, and (3) an extension of the reserve requirement base.

${ }^{4}$ Choi, Kodres, and Lu (2018) argue that cross-country coordination of macroprudential policies could reduce the probability of banking crises.

${ }^{5} \mathrm{~A}$ buffer activated in one country requires supervisory authorities in all countries to apply the same buffer on their banks' exposures into the host country (as long as the buffer does not exceed 2.5 percent of risk-weighted assets).
} 
the remaining instruments including LTV and DTI limits is voluntary. ${ }^{6}$ In the European Systemic Risk Board's (ESRB's) December 2015 reciprocity framework, the ESRB decides whether to recommend reciprocation to all member states, at the request of member states that activate a measure (ESRB 2017). In 2016, the ESRB recommended for reciprocation a Belgian measure (higher risk weights on Belgian mortgage loan exposures ${ }^{7}$ ) and an Estonian measure (1 percent systemic risk buffer for domestic exposures of all credit institutions in Estonia). ${ }^{8}$ In other cases, the ESRB also recommended to reciprocate measures: renewed Belgian, Finnish, and Swedish measures (for more details see ESRB website).

Other strategies to address cross-border circumvention include greater host control and capital flow management measures. Generally, the development of macroprudential policies helps bolster resilience in the financial system, facilitating an effective intermediation of foreign capital inflows, even in the presence of shocks. Capital flow management measures are also used to limit cross-border borrowing by domestic entities, provided that they do not substitute for warranted macroeconomic adjustment and financial sector regulation (IMF 2014b). In the EU, legal constraints prevent host jurisdictions from forcing banks to convert local branches into subsidiaries (ESRB 2017). However, in the specific context of the housing sector, other policies such as sectoral capital requirements (for example, risk weights) on specific loans, notably those denominated in foreign currency, can be raised to induce banks to hold extra capital and protect against unexpected losses from currency depreciations. Various CESEE countries have implemented such policies (Poland, Romania, Russia, Serbia).

\footnotetext{
${ }^{6}$ The ESRB goes beyond CRR/CRD IV to recommend the reciprocation of buffer rates higher than 2.5 percent (ESRB 2017).

${ }^{7}$ Article $458(5)$ CRR foresees (mandatory) reciprocation by other member states only for exposures taken by branches but not for exposures held directly across borders.

${ }^{8}$ Some member countries reciprocated only for branches or exempted individual institutions from reciprocation. Also, some member countries decided not to reciprocate these, citing the lack of material exposures (ESRB 2017).
} 
This page intentionally left blank 


\section{Chapter}

\section{Macroprudential Policies and Housing Sector Policies}

Policies other than macroprudential can affect credit and housing markets and ultimately financial stability. In this section, we briefly discuss how housing taxation and other housing sector policies can have an impact on housing prices, residential mortgages, and financial soundness.

Subsidies and preferential mortgage interest deductions are used to regulate the real estate market in many European countries. ${ }^{1}$ According to the Organisation for Economic Co-operation and Development Affordable Housing Database (OECD 2016b, pg. 1 and 2), "tax relief for access to homeownership mainly consists of tax exemptions for costs associated with the purchase of a house (for example, legal fees, stamp duty, property transfer tax) and deductibility of mortgage interests." Moreover, tax relief on costs associated with the purchase of a home are often reserved for first-time homebuyers (for example, Croatia).

Preferential mortgage interest deductibility is widely used and provides incentives to take on private debt to buy property. As mentioned by the European Commission (EC 2013, pg. 25), "housing taxation includes incentives to take on private debt to buy property by allowing the deduction of mortgage interest from personal income tax. This may-depending on the taxation of imputed rents-encourage household indebtedness, contribute to higher house prices and lead to an increased risk of financial instability, in particular in times of crisis." 2 Thus, some countries such as Denmark and Finland are reducing mortgage interest deductibility and other European countries have

\footnotetext{
${ }^{1}$ Besides tax preferences, other forms of government support to homebuyers include grants to home buyers, subsidized mortgages and mortgage guarantees for home buyers, and/or mortgage relief for over-indebted homeowners (OECD Affordable Housing Database Public Spending on Financial Support to Home Buyers).

${ }^{2}$ Neutral taxation of owner-occupied housing would require full taxation of imputed rents and capital gains on housing, combined with mortgage interest deductibility (Keen, Klemm, and Perry 2010).
} 
eliminated tax deductibility in recent years (for example, Croatia in 2010) or are in the process of phasing it out (Ireland, Spain, United Kingdom). ${ }^{3}$

To better address financial systemic risks, some European countries are shifting the tax burden toward recurrent property taxes (Figure 13). The share of immovable property taxes, relative to total tax revenues, has passed from 1.9 percent in 2005 to 2.6 percent in 2015 for a sample of 30 European countries (from 3.3 percent to 4.3 percent for EU-28). This trend would reflect that recurrent property taxes are considered to be among the least detrimental to economic growth, and could impact house prices. Table 1 presents the property tax measures adopted by European countries over the last two years and measures adopted in previous years, respectively, property taxes (for example, taxes on net wealth, taxes on property transfers, and transactions). In Denmark, for instance, upcoming property tax increases (and land reforms) are expected to reduce house price levels and volatility. ${ }^{4}$ Where foreign investment is a relevant driver of housing valuations, stamp duties on house purchases by foreigners have successfully been used to curb house price appreciation (IMF 2013a). Taxation of empty houses and other levies to discourage purchase for investment purposes (as in Israel) could have a similar effect. However, stamp duties on house purchases by foreigners and other similar measures should be periodically assessed and government should seek measures that avoid discrimination between residents and non-residents to address relevant systemic financial risks.

Countries can also use a range of structural policies to affect the real estate market and cycles. Some countries have low home ownership because the government supports investment in housing for rental purposes (for example, Germany). In Switzerland, constraints to purchase second homes, restrictions to foreign ownership, and rent controls dampen house prices. Land use policies, such as tight zoning restrictions and building codes, etc., reduce the elasticity of housing supply in some countries. Credit cycles may also be exacerbated by policies aimed at developing the mortgage market, for instance through direct government participation (IMF 2011b).

\footnotetext{
${ }^{3}$ The empirical literature is inconclusive as to the effect of interest tax deductibility on real estate cycles (see Crowe and others 2013).

${ }^{4}$ In Hungary, on the other hand, a lower value-added tax currently applies to the sale of certain types of dwelling, which contribute to the recovery in the real estate market. Aregger, Brown, and Rossi (2013) find no effect of transaction taxes or capital gains taxes on house price dynamics in Switzerland.
} 


\section{Figure 13. Property Taxes}

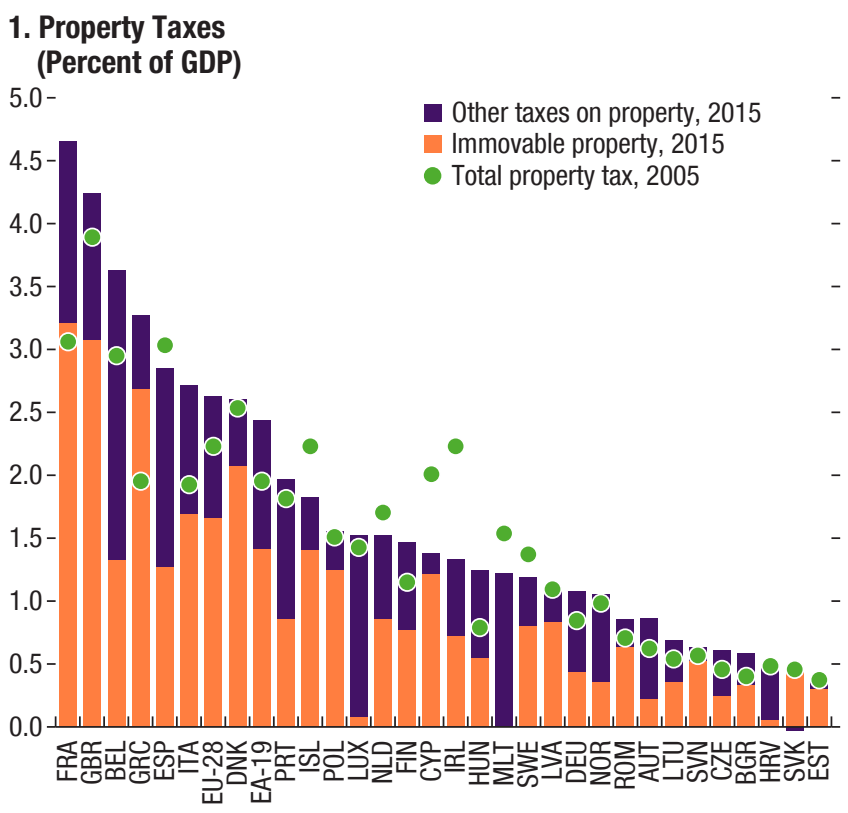

Sources: European Commission; and DG Taxation and Customs Union (Tab.73,75,77).

\section{Property Taxes (Percent of Total Taxation)}

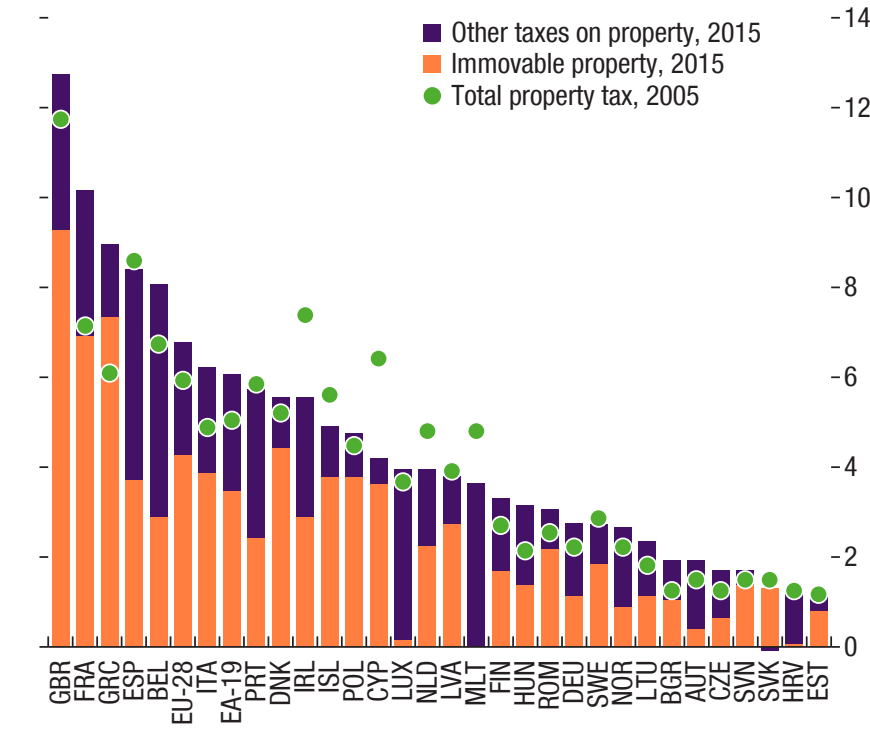

Sources: European Commission; and DG Taxation and Customs Union (Tab.74,76,78).

Table 1. Property Tax Reforms That Were Implemented, Legislative or Announced in 2016

\begin{tabular}{|c|c|c|c|c|}
\hline \multirow[b]{2}{*}{ Into Effect In } & \multicolumn{2}{|c|}{ Rate/Base (Increase) } & \multicolumn{2}{|c|}{ Rate/Base (Decrease) } \\
\hline & 2016 & 2017 or Later & 2016 & 2017 or Later \\
\hline Estate duties, inheritance and gift taxes & & GER & DNK IRL & DNK FIN GBR NLD² \\
\hline Transaction taxes on movable and immovable property & AUT GBR & BEL FRA & & \\
\hline Recurrent taxes on immovable property & FIN & FIN PRT & ITA TUR & \\
\hline Recurrent taxes on (net) wealth & ESP, ${ }^{1}$ LUX & ESP, ${ }^{1}$ LUX & NOR & NOR \\
\hline
\end{tabular}


This page intentionally left blank 


\section{ChAPTER 7 and Housing Affordability}

MaPPs can have a positive or adverse effect on housing affordability. Although in some instances MaPPs can improve affordability by taming house prices through their impact on credit-hence tackling both policy objectives-in others they can adversely affect consumption and investment and, possibly, affordability (through their effect on broader economic activity and income). However, in practice, conflicting objectives can be addressed as long as homeownership is not the primary housing tenure choice; well-functioning rental markets could play an important role here.

In addition to financial stability concerns, the rise in housing prices has led to the deterioration of affordability in a number of European economies. As shown in Figure 14, compared to their 2010 levels the price-to-income and the price to rent ratios have increased in a large proportion of European economies, where the highest increases were observed in countries such as Australia, Austria, Israel, Luxemburg, and Sweden, (an increase of about 28 percent, on average, since 2010). Moreover, in recent years, the observed deviation of the price-to-income from its long-term average has been the largest over the last 15 or 20 years for many European and non-European countries (see Figure 14). ${ }^{1}$ Similar results are also observed when analyzing the price-to-rent ratio. The highest increases were observed in countries like Israel, Luxemburg, Norway, and Sweden, (an increase of 31 percent, on average, since 2010).

Because housing affordability is an important policy goal, policymakers are often conflicted about balancing it with MaPPs. To the extent that MaPPs are

\footnotetext{
${ }^{1}$ As discussed by Osorio-Buitron and Denis (IMF 2013a), cross-country comparisons of housing valuations should internalize the effect of supply rigidities, because house prices tend to raise faster in the presence of supply constraints. One way to address this issue is to express deviations of the price-to-income and price-to-rent ratios from their long-term average in percentiles.
} 
Figure 14. Price-to-Income and Price-to-Rent Ratios
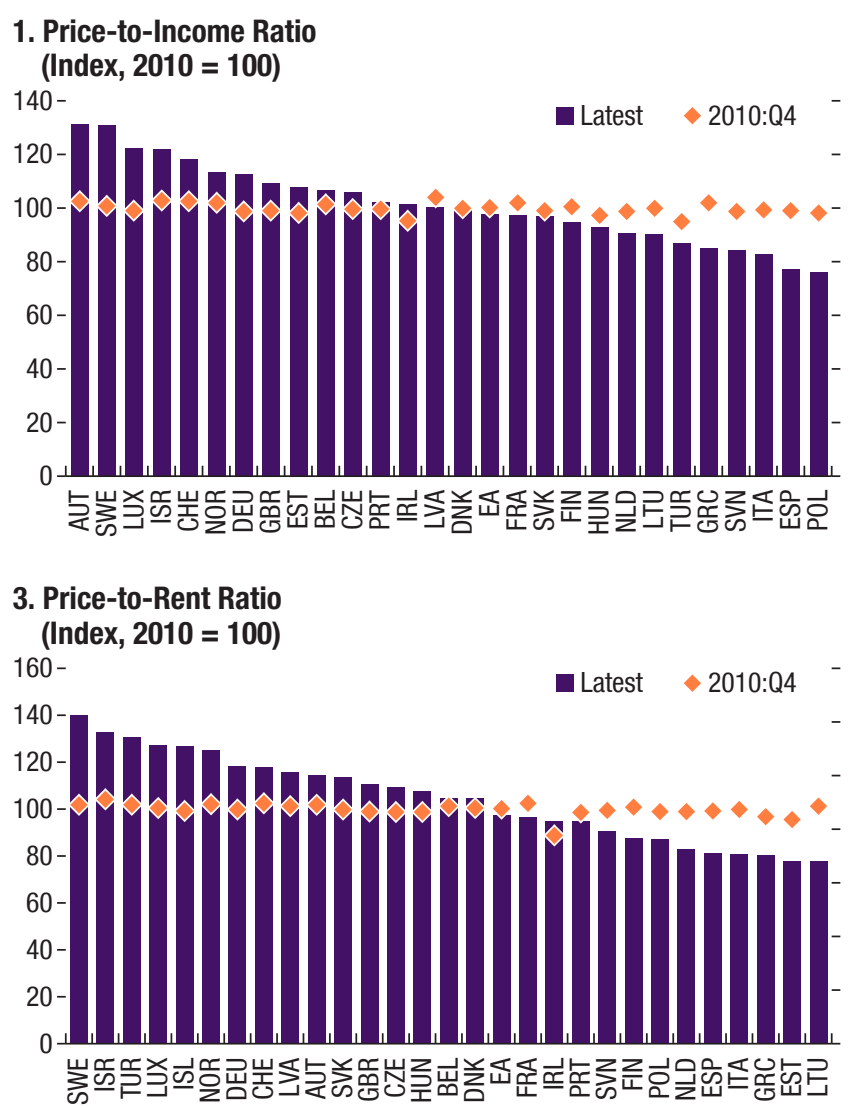

2. Price-to-Income Ratio Percentile, 2017:03 or Latest Available (100 $=$ highest in history; 0 = lowest in history)

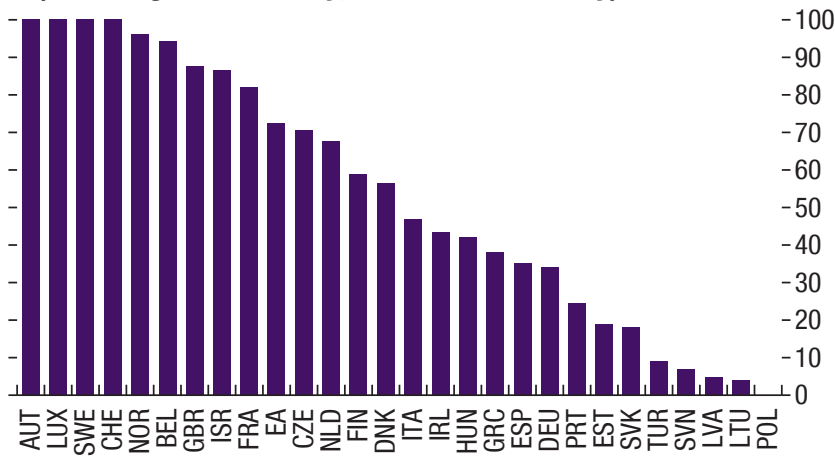

4. Price-to-Rent Ratio Percentile, 2017:03 or Latest Available (100 $=$ highest in history; $0=$ lowest in history)

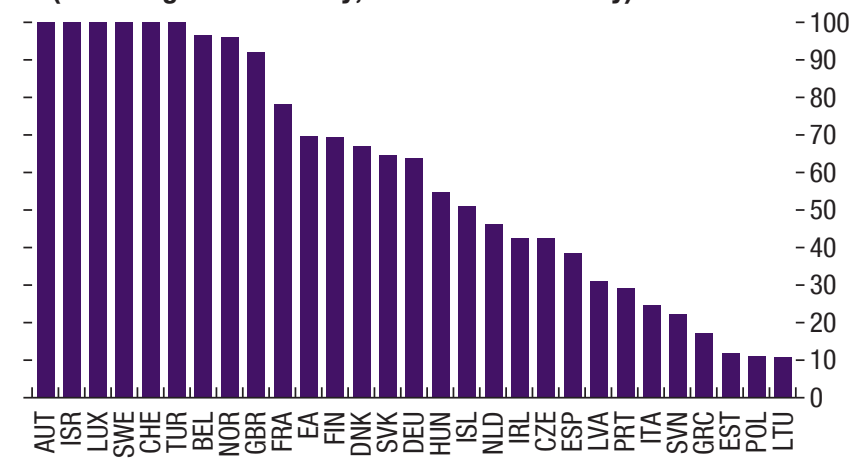

Sources: Organisation for Economic Co-operation and Development; and IMF staff calculations.

effective in reducing housing price growth, they will also make housing more affordable. However, the reduction in price will come about via a reduction in demand, as MaPPs make (some) mortgages more expensive. MaPPs will also prevent some households from becoming homeowners. The effects may be especially strong on lower-income households, which are more likely to rely on riskier mortgages (for example, high LTV/high DTI mortgages). To protect these households, policymakers can strengthen already-established policies to promote housing affordability without compromising financial stability (Table 2). These policies include (1) homeownership subsidies, (2) housing allowances, (3) social rental housing, and (4) rental support and regulation. A useful classification could divide subsidies into supply and demand 
Table 2. Housing Policy Programs Surveyed by OECD

\begin{tabular}{ll}
\hline Category & Policy Instrument \\
\hline Homeownership subsidies & Grants for access to homeownership \\
& Financial assistance for access homeownership \\
& Tax relief for access to homeownership \\
& Construction subsidies for owner-occupied housing \\
& Rent-to-buy schemes \\
& Relief for distressed mortgages \\
& Subsidies for energy efficiency and housing regeneration \\
& Taxation of residential housing \\
Housing allowances & Housing allowances in cash and vouchers \\
Social rental housing & Social rental housing \\
& Taxation of social rental housing \\
Rental support and regulation & Construction subsidies for social housing \\
& Taxation of rental housing \\
& Tax relief on paid rent for tenants \\
& Rent controls in the market rented sector \\
& Rent guarantees \\
Tenancy law
\end{tabular}

Source: Salvi del Pero et al. (2016, pg. 29).

side (Salvi del Pero and others 2016, pg. 28), which are directed to developers $^{2}$ of housing and home buyers, ${ }^{3}$ respectively.

Demand-side measures have been widely implemented in the many European countries. Owner-occupied housing receives public support in many European countries, reflecting the expected economic and social benefits associated with homeownership. However, non-targeted subsidies for homeownership could encourage household indebtedness, contribute to higher house prices and lead to an increased risk of financial instability. Policies such as housing allowances provide assistance to low income households in renting and other housing costs. ${ }^{4}$ Implemented subsidies have included, among other measures, grants to home buyers and mortgage relief for over-indebted homeowners (Salvi del Pero and others 2016). ${ }^{5}$

\footnotetext{
${ }^{2}$ Supply-side subsidies are directed at producers of housing and can consist of direct government grants or subsidies, and land and tax concessions for provision of housing.

${ }^{3}$ Demand-side subsidies are directed at consumers; common forms of demand-side housing subsidies include housing allowances, upfront grants for homebuyers, financial assistance such as subsidized interest-rate loans or mortgage guarantees and of course mortgage and property tax relief.

${ }^{4}$ Based on the OECD Affordable Housing Database (OECD 2016a, pg.1), in 2015, public spending on housing allowances is the highest in the UK at 1.4 percent of GDP, followed by France and Finland. In the case of Denmark, Germany, the Netherlands, and Sweden, public spending on housing allowances is about 0.5 percent of GDP, and between 0.1 and 0.3 percent of GDP in Austria, Bulgaria, Croatia, Czech Republic, and Ireland. No housing allowance programs were reported for Romania, the Slovak Republic, and Slovenia.

${ }^{5}$ Slavi del Pero and others (2016, pg. 36) reports that the social rental sector accounts for less than 4 percent of the total dwelling stock in Estonia, Hungary, Latvia, Portugal, and Switzerland. It accounts for between 4 and 6 percent of the stock in Germany and Norway. The Czech Republic, Finland, and the UK have an intermediate-size social rental housing sector, while the sector is relatively large in Austria, Denmark, and the Netherlands. According to the OECD Affordable Housing Database, there is no social rental housing in Croatia, Cyprus, Greece, Sweden, and Turkey.
} 
Tax deductions of mortgage interest payments, a widespread instrument of tax relief for home buyers, tend to be poorly targeted. Based on the OECD Affordable Housing Database (OECD 2016b pg. 2), for countries that apply this kind of tax relief, tax deductions of mortgage interest payments are "rarely means-tested, although they are generally, but not always, capped. Furthermore, these deductions are not always restricted to first-time home buyers." 


\section{ChAPTER}

\section{8 conclusion}

This paper documents the increasing use of MaPPs in Europe, which deal mainly with containing systemic risks across the financial system. Using MaPPs, European policymakers aimed to: (1) increase the resilience of the financial system to aggregate shocks by building and releasing buffers that help maintain the ability of the financial system to function effectively, even under adverse conditions; (2) contain the buildup of systemic vulnerabilities over time by reducing procyclical feedback between asset prices and credit and containing unsustainable increases in household debt; and (3) control structural vulnerabilities within the financial system that emerge through interlinkages, and mostly from exposures to the housing markets.

To achieve these objectives, different measures were implemented across jurisdictions. Among the most-used measures are borrower-side measures (LTVs, DTIs/LTIs, stepped-up amortization requirements) as well as bank capital requirements (countercyclical capital buffers, systemic risk buffers, systematically financial institution buffers, floors on risk weights). While some countries have introduced a comprehensive set of measures, potential leakages and circumvention seem to pose challenges, as even borrower-based measures are not always applied to all types of loans.

The case studies presented in this paper attempt to assess the effectiveness of MaPPs in addressing policy concerns mainly related to spillovers from housing markets. There is evidence that borrower-side measures, supported by lender-based measures, help limit the share of riskier mortgages, which can make economies more resilient. Specifically, in most countries following the introduction of MaPPs, the growth of high-LTV mortgages slowed down, suggesting that the measures may have been helpful. But whether MaPPs can contain the formation of house price and credit bubbles as monetary policy remains accommodative is more difficult to establish. However, lessons and empirical evidence based on these case studies remain tentative as the expe- 
rience gained in many European countries does not yet span a full financial cycle, and the wide range of institutional arrangements and policies being adopted across countries suggests that there is no one-size-fits-all approach.

MaPPs' effectiveness has, however, been circumvented, and their implementation has also generated affordability concerns. Macroprudential measures' effectiveness has been partly circumvented by nonbanks when nonbanks are subject to less-stringent regulation. Loans financed by internationally active banks have also been a source of circumvention, particularly in the Baltic and CESEE countries; thus regulatory parameters have been broadened in some jurisdictions to cover nonbanks (Annex V of IMF 2013a), but important gaps remain. In addition to financial stability concerns, the rise in housing prices has led to the deterioration of affordability in a number of European economies and in view of the importance of housing affordability as a policy goal, policymakers are often conflicted on balancing it with MaPPs.

Overall, the main policy conclusions are three-fold: (1) Fundamental drivers of house prices are often beyond the scope of MaPPs. Although a low-interest environment can affect the housing market, house prices are often the function of many other factors (supply of land, zoning restrictions, tax policy, etc.). Therefore, policymakers may remain unconcerned about housing price rises, if they are not driven by unsustainable debt level. (2) Against the accommodative monetary policy stance, this paper's findings show that MaPPs can limit riskier mortgages and contribute to stronger bank balance sheets. The question that is more difficult to answer: can MaPPs can contain the formation of house price and credit bubbles as monetary policy remains accommodative? (3) Given the many other drivers of house prices, additional policies (tax policy, mortgage-interest deductibility, zoning, construction, and planning restriction) may be needed to contain house-price bubbles, particularly if affordability becomes a concern. 


\section{References}

Aiyar, S., C.W. Calomiris, and T. Wieladek. 2014. "Does Macro-Prudential Regulation Leak? Evidence from a UK Policy Experiment." Journal of Money, Credit, and Banking 46 (1): 181-214.

Akinci, O., and J. Olmstead-Rumsey. 2015. "How Effective are Macroprudential Policies? An Empirical Investigation.” International Finance Discussion Paper, No. 1136 Board of Governors of the Federal Reserve System, Washington, DC.

Alam and others. 2019. "Digging Deeper-Evidence on the Effects of Macroprudential Policies from a New Database.” IMF Working Paper No. 19/66, International Monetary Fund, Washington, DC.

Aregger, N., M. Brown, and E. Rossi. 2013. "Transaction Taxes, Capital Gains Taxes and House Prices." Swiss National Bank Working Papers 2013-2, Zurich.

Bakker, B. B., and A.-M. Gulde. 2010. "The Credit Boom in the EU New Member States: Bad Luck or Bad Policies?” IMF Working Paper, No. 10/130 International Monetary Fund, Washington.

Basel Committee on Banking Supervision (BCBS). 2010. Guidance for National Authorities Operating the Countercyclical Capital Buffer. Basel: Bank for International Settlements.

Buchak, G., G. Matvos, T. Piskorski, and A. Seru. 2017. "Fintech, Regulatory Arbitrage, and the Rise of Shadow Banks." NBER Working Paper No. 23288, National Bureau of Economic Research, Cambridge, MA.

Budnik, K., and J. Kleibl. 2018. "Macroprudential Regulation in the European Union in 1995-2014: Introducing a New Data Set on Policy Actions of a Macroprudential Nature." ECB Working Paper No. 2123, European Central Bank, Frankfurt. 
Buch, C., and L. S. Goldberg. 2017. "Cross-Border Prudential Policy Spillovers: How Much? How Important? Evidence from the International Banking Research Network.” International Journal of Central Banking 13(S1): 505-58.

Cerutti, E., J. Dagher, and G. Dell'Ariccia. 2015. "The Use and Effectiveness of Macroprudential Policies: New Evidence.” IMF Working Paper 15/61, International Monetary Fund, Washington, DC.

— 2017. "Housing Finance and Real-Estate Booms: A Cross-Country Perspective." Journal of Housing Economics 38 (December): 1-13.

Choi, S.M., L. Kodres, and J. Lu. 2018. "Friend or Foe? Cross-Border Linkages, Contagious Banking Crises, and 'Coordinated' Macroprudential Policies.” IMF Working Paper, No. 18/9, International Monetary Fund, Washington, DC.

Cizel, Janko, J. Frost, A. Houben, and P. Wierts. 2016. "Effective Macroprudential Policy: Cross-Sector Substitution from Price and Quantity Measures.” IMF Working Paper No. 16/94 International Monetary Fund, Washington, DC.

Claessens, S., S. R., Ghosh, and R. Mihet. 2013. "Macro-Prudential Policies to Mitigate Financial System Vulnerabilities." Journal of International Money and Finance 39: 153-85.

Craig R. S., and C. Hua. 2011. "Determinants of Property Prices in Hong Kong SAR: Implications for Policy.” IMF Working Paper 11/277, International Monetary Fund, Washington, DC.

Crowe, C., G. Dell'Ariccia, D. Igan, and P. Rabanal. 2013. "How to Deal with Real Estate Booms: Lessons from Country Experiences." Journal of Financial Stability 9 (3): 300-19.

Dimova, D., P. Kongsamut, and J. Vandenbussche. 2016. "Macroprudential Policies in Southeastern Europe." IMF Working Paper 16/29, International Monetary Fund, Washington, DC.

Egert, B., and D. Mihaljek. 2007. "Determinants of House Prices in Central and Eastern Europe." Comparative Economic Studies 49(3): 367-88.

European Commission (EC). 2012. "Tax Reforms in EU Member States: 2012: Tax Policy Challenges for Economic Growth and Fiscal Sustainability." European Economy 6-2012, Brussels.

. 2013. “Tax Reforms in EU Member States 2013: Tax Policy Chal-

lenges for Economic Growth and Fiscal Sustainability." Taxation Papers, Working Paper N. 38-2013, Brussels. 
2014. “Tax Reforms in EU Member States 2012: Tax Policy Challenges for Economic Growth and Fiscal Sustainability." European Economy 6-2012, Brussels.

- 2015. “Tax Reforms in EU Member States: 2015 Report.” Taxation Papers, Working Paper N. 58-2015, Brussels.

. 2017. "Taxation Trends in the European Union.” DG Taxation and Customs Union, Brussels.

European Systemic Risk Board (ESRB). 2016. "Macroprudential Policy beyond Banking: An ESRB Strategy Paper.” ESRB Strategy Paper, Frankfurt.

\section{- 2017. A Review of Macroprudential Policy in the EU. Frankfurt.}

Financial Stability Board (FSB). 2016. "Thematic Review on the Implementation of the FSB Policy Framework for Shadow Banking Entities.” FSB Peer Review Report, Basel.

Gambacorta, L., and A. Murcia. 2017. "The Impact of Macroprudential Policies and Their Interaction with Monetary Policy: An Empirical Analysis Using Credit Registry Data.” BIS Working Paper, No. 636, Bank for International Settlements, Basel.

Geng, N. 2018. "Fundamental Drivers of House Prices in Advanced Economies.” IMF Working Paper, No. 18/164, International Monetary Fund, Washington, DC.

Girouard, N., M. Kennedy, P. van den Noord, and C. André. 2006. "Recent House Price. Developments: The Role of Fundamentals.” OECD Economics Department Working Papers, No. 475, Organisation for Economic Co-operation and Development, Paris.

Herzberg, V., and M. Watson. 2014. "Macroprudential Policies in the Euro Area: Issues for the Next Ten Years.” University of Oxford, Oxford.

Igan, D., and H. Kang. 2011. "Do Loan-to-Value And Debt-to-Income Limits Work? Evidence from Korea.” IMF Working Paper 11/297, International Monetary Fund, Washington, DC.

International Monetary Fund, Financial Stability Board, and Bank for International Settlements (IMF-FSB-BIS). 2016. "Elements of Effective Macroprudential Policies: Lessons from International Experience.” August 31.

International Monetary Fund (IMF). 2011a. "Macroprudential Policy: An Organizing Framework." IMF Policy Paper, International Monetary Fund, Washington, DC. 2011b. Global Financial Stability Report. Washington, DC, April. 
. 2013a. "Key Aspects of Macroprudential Policy." IMF Policy Paper, Washington, DC. . 2013b. "Key Aspects of Macroprudential Policy-Background Paper." IMF Policy Paper, Washington, DC. . 2013c. "The Interaction of Monetary and Macroprudential Policies."

IMF Policy Paper, Washington, DC.

. 2014a. Global Financial Stability Report. Washington, DC, October.

. 2014b. "Staff Guidance Note on Macroprudential Policy."

Washington, DC. . 2014c. "Staff Guidance Note on Macroprudential Policy." IMF Policy

Paper, Washington, DC.

. 2014d. "Staff Guidance Note on Macroprudential Policy-Detailed

Guidance on Instruments." IMF Policy Paper, Washington, DC.

. 2016. "Tax Policy, Leverage, and Macroeconomic Stability." IMF

Policy Paper, Washington, DC.

. 2017. Global Financial Stability Report." Washington, DC, October. . 2014. "Staff Guidance Note on Macroprudential Policy." IMF Policy

Paper, December Washington: International Monetary Fund.

. 2014. "Staff Guidance Note on Macroprudential Policy-Detailed

Guidance on Instruments." IMF Policy Paper, Washington, DC.

_. 2016. "Iceland: Selected Issues." Washington, DC.

. 2016. "Sweden: Selected Issues." Washington, DC.

. 2017. "Norway: Selected Issues." Washington, DC.

. 2017. "The Netherlands: Selected Issues." Washington, DC.

. 2017. "Sweden: Staff Report." Washington, DC.

. 2017. "Israel: Staff Report." Washington, DC.

. 2017. "Housing Market Developments in Advanced Economies and

Policy Issues.” SPR Department Paper, Washington, DC.

Jacome, L. I., and M. Srobona. 2015. "LTV and DTI Limits-Going

Granular.” IMF Working Paper 15/154, International Monetary Fund, Washington, DC.

Kang, H., and others. 2017. "Macroprudential Policy Spillovers: A Quantitative Analysis." IMF Working Paper, 17/170, International Monetary Fund, Washington, DC. 
Keen, M., A. Klemm, and V. Perry. 2010. "Tax and the Crisis.” Fiscal Studies 31 (1): 43-79.

Kholodilin, K. A., and D. Ulbricht. 2015. "Urban House Prices: A Tale of 48 Cities." Economics 9: 1-43.

Kuttner, K., and I. Shim. 2016. "Can Non-Interest Rate Policies Stabilize Housing Markets? Evidence from a Panel of 57 Economies.” Journal of Financial Stability 26 (C): 31-44.

Lim, C. and others. 2011. "Macroprudential Policy: What Instruments and How to Use Them? Lessons from Country Experiences." IMF Working Paper 11/238, International Monetary Fund, Washington, DC.

Næss-Schmidt, S., J. Bjarke Jensen, C. Heebøll, and P. Søre. 2017. The Role of Macroprudential Policy in Sweden. Copenhagen: Copenhagen Economics.

Organisation for Economic Co-operation and Development (OECD). 2016a. "Public Spending on Housing Allowances." Public Policies Towards Affordable Housing PH3.1, Affordable Housing Database, Paris.

— 2016b. "Tax Relief for Access to Home Ownership." Public Policies Towards Affordable Housing PH2.2, Affordable Housing Database, Paris.

Poghosyan, T. 2019. "How Effective is Macroprudential Policy? Evidence from Lending Restriction Measures in EU Countries." IMF Working Paper WP/19/45, International Monetary Fund, Washington, DC.

Reinhardt, D., and R. Sowerbutts. 2015. "Regulatory Arbitrage in Action: Evidence from Banking Flows and Macroprudential Policy." Bank of England Working Paper No. 546, London.

Salvi del Pero, A., W. Adema, V. Ferraro, and V. Frey. 2016. "Policies to Promote Access to Good-Quality Affordable Housing in OECD Countries." OECD Social, Employment and Migration Working Papers No. 176, Organisation for Economic Co-operation and Development, Paris.

Sutt, A., H. Korju, and K. Siibak. 2011. "The Role of Macro-Prudential Policies in the Boom and Adjustment Phase of the Credit Cycle in Estonia.” Policy Research Working Paper No. WPS 5835, World Bank, Washington, DC.

Vandenbussche, J., U. Vogel, and E. Detragiache. 2012. "Macroprudential Policies and Housing Prices-A New Database and Empirical Evidence for Central, Eastern, and South-Eastern Europe.” IMF Working Paper 12/303, International Monetary Fund, Washington, DC. 